Prepared in cooperation with the Kootenai Tribe of Idaho and Idaho Department of Fish and Game, and Bonneville Power Administration
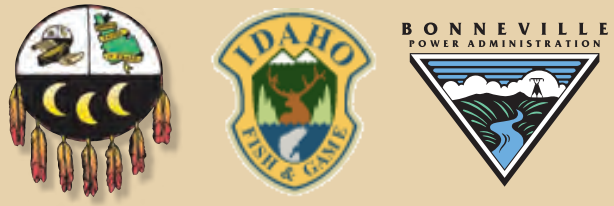

\title{
Simulation of Streamflow Using a Multidimensional Flow Model for White Sturgeon Habitat, Kootenai River near Bonners Ferry, Idaho-A Supplement to Scientific Investigations Report 2005-5230
}

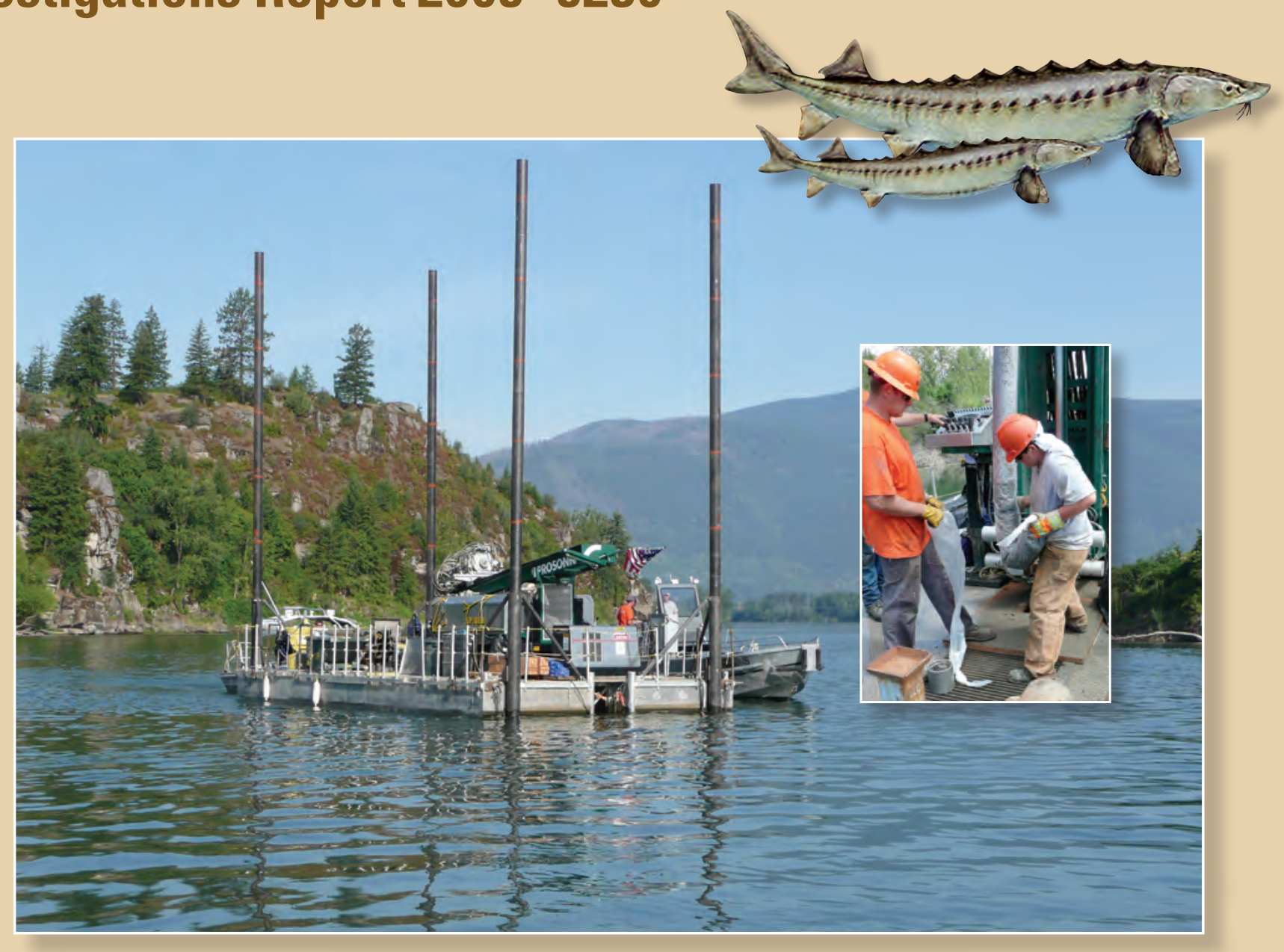

Scientific Investigations Report 2009-5026 
Cover: Cover photos show a drilling barge used to collect sediment cores at 23 locations in the Kootenai River near Bonners Ferry, Idaho. U.S. Geological Survey scientists developed a geologist log for each core and used the information to map the geology beneath the river and nearby floodplain. (Photographs were taken by Gary Barton of the U.S. Geological Survey facing west towards Ambush Rock in June 2007. 


\section{Simulation of Streamflow Using a Multidimensional Flow Model for White Sturgeon Habitat, Kootenai River near Bonners Ferry, Idaho-A Supplement to Scientific Investigations Report 2005-5230}

By Gary J. Barton, Richard R. McDonald, and Jonathan M. Nelson

Prepared in cooperation with the Kootenai Tribe of Idaho, Idaho Department of

Fish and Game, and Bonneville Power Administration

Scientific Investigations Report 2009-5026 


\section{U.S. Department of the Interior \\ KEN SALAZAR, Secretary \\ U.S. Geological Survey \\ Marcia K. McNutt, Director}

\section{U.S. Geological Survey, Reston, Virginia: 2009}

For more information on the USGS - the Federal source for science about the Earth, its natural and living resources, natural hazards, and the environment, visit http://www.usgs.gov or call 1-888-ASK-USGS

For an overview of USGS information products, including maps, imagery, and publications, visit http://www.usgs.gov/pubprod

To order this and other USGS information products, visit http://store.usgs.gov

Any use of trade, product, or firm names is for descriptive purposes only and does not imply endorsement by the U.S. Government.

Although this report is in the public domain, permission must be secured from the individual copyright owners to

reproduce any copyrighted materials contained within this report.

Suggested citation:

Barton, G.J., McDonald, R.R., and Nelson, J.M., 2009, Simulation of streamflow using a multidimensional flow model for white sturgeon habitat, Kootenai River near Bonners Ferry, Idaho-A supplement to Scientific Investigations Report 2005-5230: U.S. Geological Survey Scientific Investigations Report 2009-5026, 34 p. 


\section{Contents}

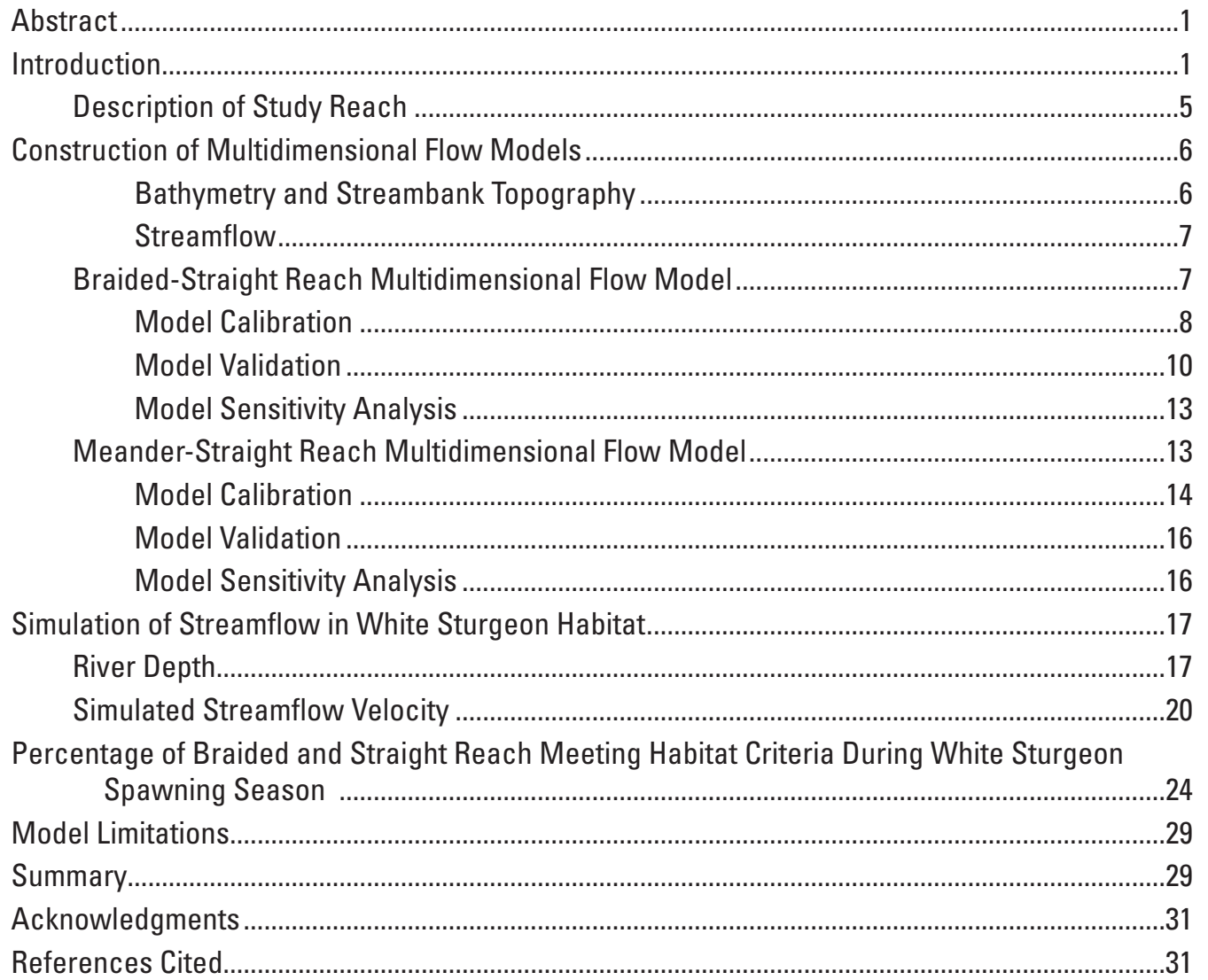

\section{Figures}

Figure 1. Map showing location of study area near Bonners Ferry, Idaho, and selected streamflow-gaging stations and dams in the Kootenai River drainage basin, Idaho, Montana, and British Columbia, Canada ..................................

Figure 2. Map showing location of upstream and downstream boundaries for multidimensional flow models, selected streamflow-gaging stations and data-collection sites, and simulated depth, Kootenai River near Bonners Ferry, Idaho, 2005-06

Figure 3. Graph showing location and number of white sturgeon spawning events, Kootenai River near Bonners Ferry, Idaho, 1994-2001

Figure 4. Map showing nodes forming an approximately 10 by 10 -meter grid in the multidimensional flow model at river kilometer 247.3 to 249.3 in the braided reach of the Kootenai River near Bonners Ferry, Idaho 


\section{Figures-Continued}

Figure 5. Graph showing drag coefficient and lateral eddy viscosity for the calibrated braided-straight reach multidimensional flow model, Kootenai River near Bonners Ferry, Idaho

Figure 6. Graphs showing measured cross sections of vertically averaged velocities and corresponding simulated velocities in the braided reach, for streamflow ranging from 825 to 860 cubic meters per second, Kootenai River near Bonners Ferry, Idaho, May 25-26, 2005

Figure 7. Aerial photograph showing gravel bars in the braided reach and polygons representing locations where variable drag coefficients were applied in the braided-straight reach model, Kootenai River near Bonners Ferry, Idaho, 2002 .. 12

Figure 8. Graph showing drag coefficient and lateral eddy viscosity for the calibrated multidimensional flow model of the meander-straight reach, Kootenai River near Bonners Ferry, Idaho

Figure 9. Graphs showing white sturgeon spawning event locations and simulated average depth for five streamflows at cross sections positioned every 100 meters along meander, straight, and braided reaches, Kootenai River near Bonners Ferry, Idaho

Figure 10. Graphs showing white sturgeon spawning event locations and maximum depth for five streamflows at cross sections positioned every 100 meters along the meander, straight, and braided reaches, Kootenai River near Bonners Ferry, Idaho

Figure 11. Graphs showing white sturgeon spawning event locations and simulated average and maximum velocity for five streamflows at cross sections positioned every 100 meters along the meander, straight, and braided reaches, Kootenai River near Bonners Ferry, Idaho. ....

Figure 12. Aerial photographs showing distribution of simulated velocity for five streamflows in the meander, straight, and braided reaches, Kootenai River near Bonners Ferry, Idaho

Figure 13. Graph showing streamflow and percentage of thalweg longitudinal profile achieving a minimum water depth of 5 and 7 meters between river kilometer 244.6 and 252.7, Kootenai River near Bonners Ferry, Idaho, May 18-June 5, 2006, and May 22-June 5, 2007

Figure 14. Graph showing streamflow and percentage of longitudinal profile achieving a minimum water column velocity of 1 meter per second between river kilometer 244.6 and 252.7, Kootenai River near Bonners Ferry, Idaho, June 6-30, 2006, and 2007 


\section{Tables}

Table 1. Calibration summary for the multidimensional flow model for the braided-straight reach of the Kootenai River near Bonners Ferry, Idaho, 2006 ..... 8

Table 2. Sensitivity analysis and results of the multidimensional flow model streamflow simulations for the braided-straight reach, Kootenai River near Bonners Ferry,

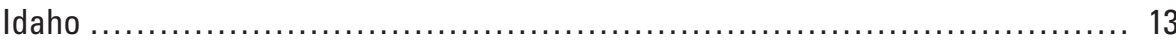

Table 3. Calibration summary for the multidimensional flow model for the meander-straight reach, Kootenai River near Bonners Ferry, Idaho

Table 4. Sensitivity analysis and results of the multidimensional flow model for simulated streamflows in the meander-straight reach, Kootenai River near Bonners Ferry, Idaho

Table 5. Upstream and downstream boundary conditions in simulations from the multidimensional flow models of the Kootenai River near Bonners Ferry, Idaho $\ldots 17$

Table 6. Streamflow, surface-water elevation, and length and percentage of a longitudinal profile between river kilometers 244.6 and 252.7 meeting depth and velocity habitat criterion, Kootenai River near Bonners Ferry, Idaho, May 18-June 30, 2006, and May 22-June 30, 2007

\section{Conversion Factors, Datums, and Abbreviations and Acronyms}

Conversion Factors

\begin{tabular}{lcl}
\hline \multicolumn{1}{c}{ Multiply } & By & \multicolumn{1}{c}{ To obtain } \\
\hline cubic meter per second $\left(\mathrm{m}^{3} / \mathrm{s}\right)$ & 70.07 & acre-foot per day \\
cubic meter per second $\left(\mathrm{m}^{3} / \mathrm{s}\right)$ & 35.31 & cubic foot per second \\
kilometer $(\mathrm{km})$ & 0.6214 & mile \\
meter $(\mathrm{m})$ & 3.281 & foot \\
meter per second $(\mathrm{m} / \mathrm{s})$ & 3.281 & foot per second \\
\hline
\end{tabular}

Pressure: 1 Pascal $(\mathrm{Pa})=1 \mathrm{~N} / \mathrm{m}^{2}=6.895 \mathrm{kPa}$

Temperature in degrees Celsius $\left({ }^{\circ} \mathrm{C}\right)$ may be converted to degrees Fahrenheit $\left({ }^{\circ} \mathrm{F}\right)$ as follows:

${ }^{\circ} \mathrm{F}=\left(1.8 \mathrm{x}^{\circ} \mathrm{C}\right)+32$.

\section{Datums}

Vertical coordinate information is referenced to the North American Vertical Datum of 1988 (NAVD 88).

Horizontal coordinate information is referenced to the North American Datum of 1929 (NAD 29) and Idaho Transverse Mercator - North American Datum 1983/1998 Idaho West, in meters. 


\title{
Conversion Factors, Datums, and Abbreviations and Acronyms-Continued
}

\author{
Abbreviations and Acronyms \\ ADCP acoustic Doppler current profiler \\ GPS Global Positioning System \\ GUI Graphical User Interface \\ IDFG Idaho Department of Fish and Game \\ KTOI Kootenai Tribe of Idaho \\ LEV lateral eddy viscosity \\ LIDAR Light Detection and Ranging \\ RKM river kilometer \\ USFWS U.S. Fish and Wildlife Service \\ USGS U.S. Geological Survey
}




\title{
Simulation of Streamflow Using a Multidimensional Flow Model for White Sturgeon Habitat, Kootenai River near Bonners Ferry, Idaho - Supplement to Scientific Investigations Report 2005-5230
}

\author{
By Gary J. Barton, Richard R. McDonald, and Jonathan M. Nelson
}

\section{Abstract}

During 2005, the U.S. Geological Survey (USGS) developed, calibrated, and validated a multidimensional flow model for simulating streamflow in the white sturgeon spawning habitat of the Kootenai River in Idaho. The model was developed as a tool to aid understanding of the physical factors affecting quality and quantity of spawning and rearing habitat used by the endangered white sturgeon (Acipenser transmontanus) and for assessing the feasibility of various habitat-enhancement scenarios to re-establish recruitment of white sturgeon. At the request of the Kootenai Tribe of Idaho, the USGS extended the two-dimensional flow model developed in 2005 into a braided reach upstream of the current white sturgeon spawning reach. Many scientists consider the braided reach a suitable substrate with adequate streamflow velocities for re-establishing recruitment of white sturgeon. The 2005 model was extended upstream to help assess the feasibility of various strategies to encourage white sturgeon to spawn in the reach. At the request of the Idaho Department of Fish and Game, the USGS also extended the two-dimensional flow model several kilometers downstream of the white sturgeon spawning reach. This modified model can quantify the physical characteristics of a reach that white sturgeon pass through as they swim upstream from Kootenay Lake to the spawning reach. The USGS Multi-Dimensional Surface-Water Modeling System was used for the 2005 modeling effort and for this subsequent modeling effort. This report describes the model applications and limitations, presents the results of a few simple simulations, and demonstrates how the model can be used to link physical characteristics of streamflow to the location of white sturgeon spawning events during 1994-2001.
Model simulations also were used to report on the length and percentage of longitudinal profiles that met the minimum criteria during May and June 2006 and 2007 as stipulated in the U.S. Fish and Wildlife Biological Opinion.

\section{Introduction}

The Kootenai River White Sturgeon Recovery Team (U.S. Fish and Wildlife Service, 1999; 2000), composed of scientists and engineers from the U.S. Fish and Wildlife Service (USFWS), Kootenai Tribe of Idaho (KTOI), Idaho Department of Fish and Game (IDFG), and several local, State, Federal, and Canadian agencies, is working to understand the physical factors affecting quality and quantity of spawning and rearing habitat used by the endangered white sturgeon (Acipenser transmontanus) and to assess the feasibility of various habitat-enhancement scenarios to re-establish recruitment of white sturgeon. To that end, the U.S. Geological Survey (USGS) developed a two-dimensional flow model of the Kootenai River near Bonners Ferry, Idaho (Barton and others, 2005). The reach used for this model extended from river kilometer (RKM) 245.9 in Bonners Ferry to near Shorty's Island (RKM 228.4) (figs. 1 and 2). The 2005 model consisted of a straight reach and a meander reach and included all observed white sturgeon spawning sites. The recovery team are using the model simulation results to design and implement ways to improve that habitat. Model simulations have proved useful in linking streamflow velocities and depths to spawning location and other habitat data (Barton and others, 2006a, 2006b, and 2006c; McDonald and others, 2006a). 


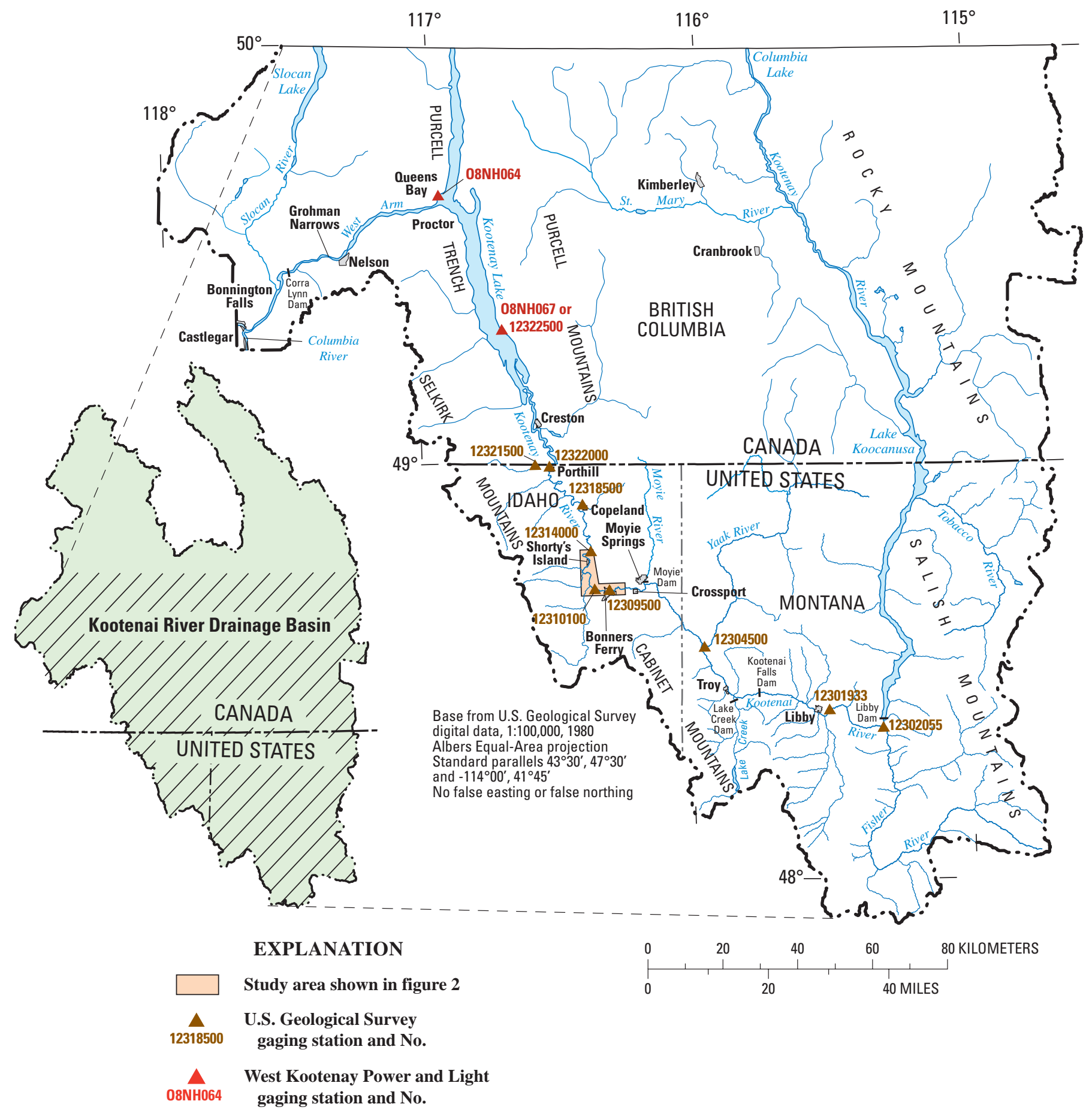

Figure 1. Location of study area near Bonners Ferry, Idaho, and selected streamflow-gaging stations and dams in the Kootenai River drainage basin, Idaho, Montana, and British Columbia, Canada. 


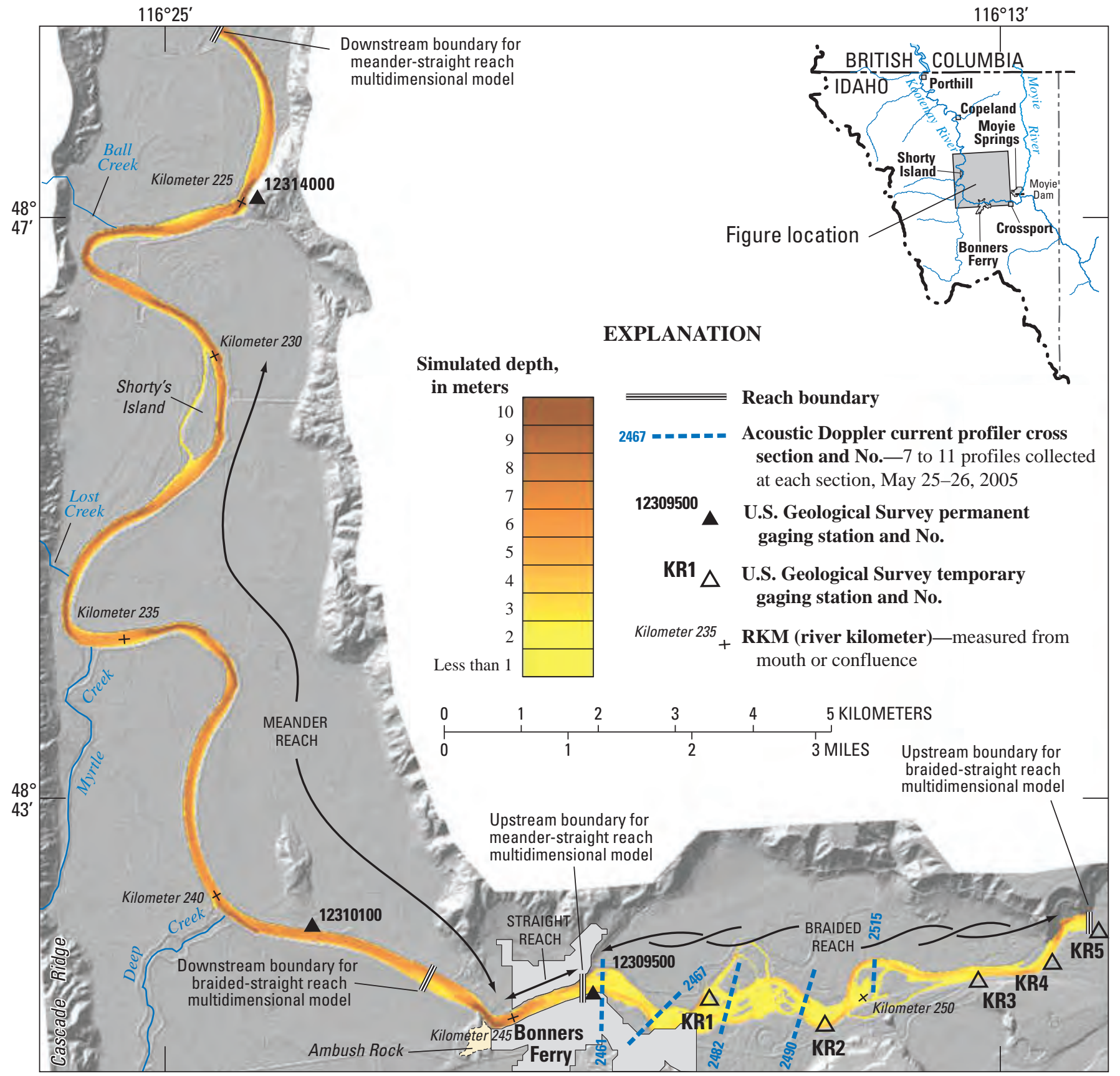

LIDAR data provided bt Kootenai Tribe of Idaho

Figure 2. Location of upstream and downstream boundaries for multidimensional flow models, selected streamflow-gaging stations and data-collection sites, and simulated depth, Kootenai River near Bonners Ferry, Idaho, 2005-06. River depth is based on median water-surface elevation in Kootenay Lake, British Columbia, Canada, for a streamflow of 850 cubic-meters per second. 
The KTOI requested that the USGS construct the two-dimensional flow model of a braided reach upstream of the present-day white sturgeon spawning reach (ㅍg. 2 ). Extending the 2005 modeling effort upstream into the braided reach is important because many scientists consider the braided reach a suitable substrate with adequate streamflow velocities for re-establishing recruitment of white sturgeon. Furthermore, sturgeon have been caught during the spawning season as recently as 1978 at Crossport (fig. 1), near RKM 252 in the braided reach (J.P. Runyan, resident, Bonners Ferry, Idaho, oral commun., 2006). The model of the braided reach was used to quantify physical characteristics of the reach that white sturgeons seldom inhabit. White sturgeon egg collection (fig. 3 ) and telemetry data indicate that most spawning currently is within the meander reach between
RKMs 228 and 240. During 2001 and 2006, spawning also was observed in the straight reach between RKMs 245.0 and 245.8 (Paragamian and others, 2001; 2002). The spawning reach is defined here to range from RKMS 228 to 245.8 . However, during the 1999 though 2006 spawning seasons about 10-67 percent of the annual spawning white sturgeon population briefly inhabited the lowermost part of the braided reach (Pete Rust, Idaho Fish and Game, oral commun., 2006). For this reason, the IDFG requested that the USGS also extend the two-dimensional flow model of the spawning reach several kilometers downstream of the white sturgeon spawning reach. This modified model was used to quantify the physical characteristics of a reach that white sturgeon passed through as they swim upstream from Kootenay Lake to the spawning reach.

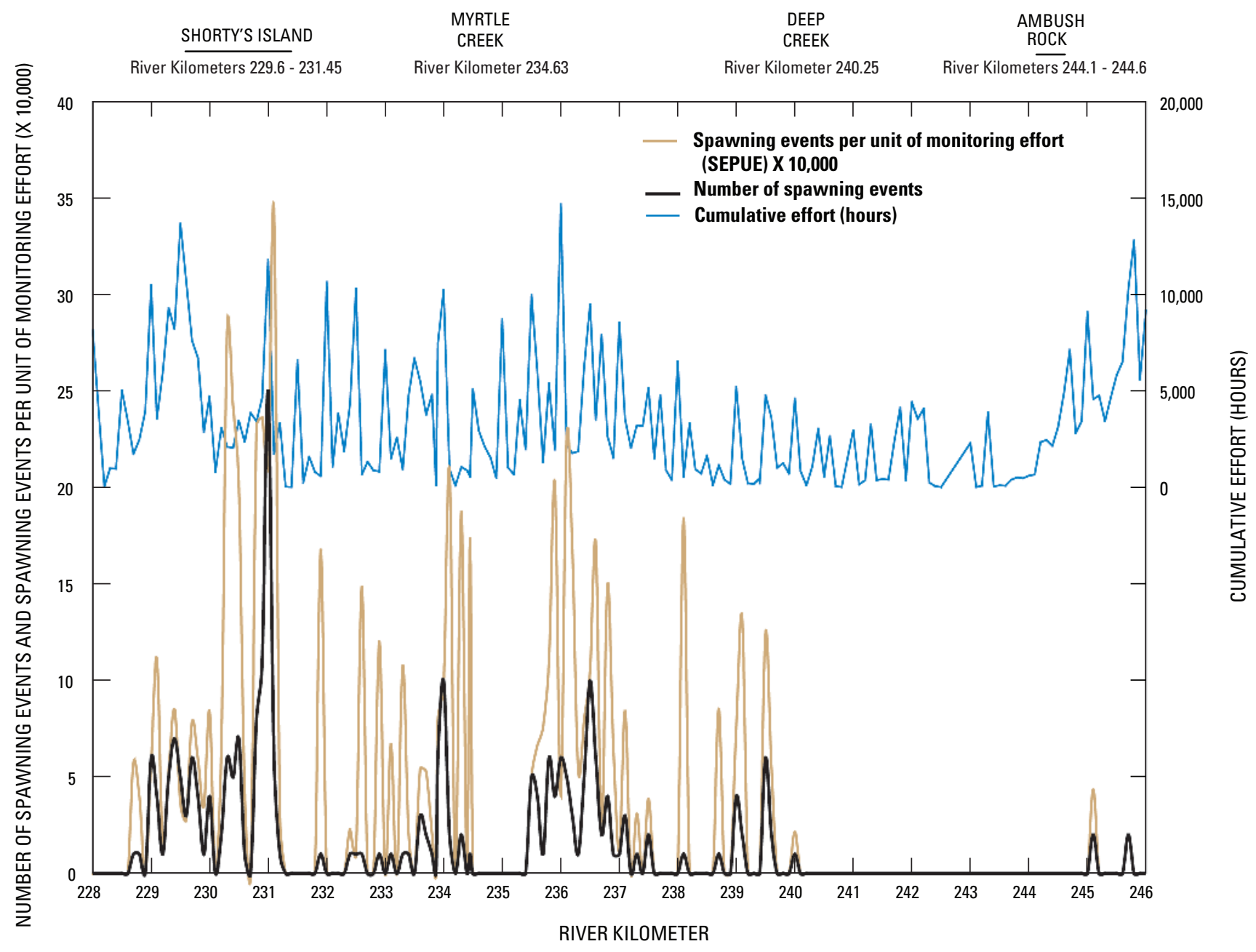

Figure 3. Location and number of white sturgeon spawning events, Kootenai River near Bonners Ferry, Idaho, 1994-2001. Spawning data provided by Idaho Department of Fish and Game, written commun., 2005. Spawning event per unit effort (SEPUE) is the number of times fertilized eggs were detected on an egg mat resting on the riverbed at a sampling site divided by the time the mat was deployed. Egg mats were retrieved, examined, and replaced every 24 to 48 hours. 
This report documents two overlapping two-dimensional flow models that include the braided reach, straight reach, and meander reach. When combined, these models form a contiguous $31.8 \mathrm{~km}$ model reach from RKM 222.2 to 254.0. The upstream model extends from RKM 242.9 to 254.0, and includes the braided reach, the $2.8 \mathrm{~km}$ straight reach, and a $1.6 \mathrm{~km}$ segment of the meander reach. This model is called the braided-straight reach multidimensional model (fig. 2). The second model is a modified version of the two-dimensional flow model developed by Barton and others (2005), which included the meander reach and the straight reach. For this study, the previous model was extended $6.2 \mathrm{~km}$ downstream. The modified model extends from RKM 222.2 to 245.9 (fig. 2). In this report, the modified model is referred as the meander-straight reach multidimensional model. The straight reach was included in the meander-straight reach model to improve model simulation in the meander reach. Locating the model boundary upstream of the area of interest improves model behavior for that area.

This report presents the braided-straight reach multidimensional model and documents modifications to the meander-straight reach model not included in Barton and others (2005). This report also presents results of a few simple simulations that can be used to link stream depths and streamflow velocities to biological or other habitat data.

\section{Description of Study Reach}

A brief description of the study reach (figs. 1 and $\underline{2}$ ) and white sturgeon spawning habitat is provided below. Further details are provided in previous USGS reports: Barton (2004); Barton and others (2005); Berenbrock and Bennett (2005); and McDonald and others (2006a).

Kootenay Lake, British Columbia, Canada, creates backwater conditions in the Kootenai River to a reach that extends from the mouth of Deep Creek (RKM 240.25) to several kilometers upstream of Bonners Ferry (fig. 2). The extent of backwater is a function of river flows upstream of the backwater reach and Kootenay Lake levels. During periods of low streamflow, backwater conditions diminish and freeflowing water may extend a few kilometers downstream of
RKM 245.9. A detailed analysis of the location of transition between the free-flowing river and backwater under a range of streamflow conditions is presented in Berenbrock (2005).

Based on historical data collected at the Copeland gage (12318500) 1966 to 1971, during the pre-Libby Dam era, the median annual peak spring-summer streamflow was about $2,240 \mathrm{~m}^{3} / \mathrm{s}$. The annual peak spring-summer runoff streamflow during the beginning of the Libby Dam era, 1970s through 1980 s, was several times less than during the pre-Libby Dam era (Barton, 2003). Studies on Kootenai River white sturgeon during the past few decades indicated a problem in sturgeon recruitment. Since the mid-1990s, the U.S. Fish and Wildlife Service requested that Kootenai River streamflows be increased during white sturgeon spawning in May and June in an attempt to help re-establish recruitment. Kootenai River streamflows are augmented with additional release of water from Libby Dam; however, the median streamflow during spawning season is about one-half that of the pre-Libby Dam era. Recruitment occurs when a spawning event produces juvenile fish that survive to create a new year-class of fish in sufficient numbers to maintain the fish population.

Prior to the 1960s, dikes were constructed on the river's natural levee throughout the study area for flood protection. The upper part of the study area is a braided reach that courses over gravel and cobbles and some sand. This reach extends downstream to a straight reach near RKM 245.9. The straight reach (Tetra Tech, Inc., 2003) lies between RKMs 244.5 and 245.9 and forms a transition zone between the braided reach and the meander reach. Here, the riverbed consists of gravel, sand, and traces of cobble and rock crop out along the banks in a few areas. The meander reach, downstream of the straight reach, is dominated by sand dunes with minor amounts of lacustrine clay and silt in the thalweg and along the outside bank of meanders. Small, isolated gravel lenses buried by a thin layer of sand also were identified at RKMs 243.8 and 241.6. In a few cases, gravel and cobble are in the riverbed near Myrtle Creek, and at the mouth of Lost Creek and Ball Creek. The source of this coarse-grained riverbed substrate may be an alluvial fan at the base of Cascade Ridge or the sediment that forms the dike along the left bank. Some riprap has rolled down the toe of the dike into the channel (Barton, 2004). 


\section{Construction of Multidimensional Flow Models}

The USGS Multi-Dimensional Surface-Water Modeling System (MD_SWMS) was used in this study and in the previous study (Barton and others, 2005) to simulate watersurface elevation, water depth, depth-averaged water velocity, boundary (bed) shear stress, and sediment mobility. MD_ SWMS has a graphical user interface (GUI) developed by the USGS (McDonald and others, 2001) for hydrodynamic models. FaSTMECH is one computational model within MD_SWMS that was developed at the USGS (Nelson and Smith, 1989; Nelson and McDonald, 1997; Thompson and others, 1998; Lisle and others, 2000; Nelson and others, 2003; McDonald, and others, 2006b; and McDonald, and others, 2006c). FaSTMECH is a quasi-three-dimensional model, often referred to as a 2.5-dimensional model, which includes a two-dimensional vertically averaged flow computation and a method for computing the vertical structure of the flow. FaSTMECH treats the vertical structure of the primary flow (flow along the vertically averaged streamlines) and secondary flows associated with curvature (Nelson and others, 2003). The computational grid used in FaSTMECH is a curvilinear orthogonal coordinate system with a user-defined centerline. Physical assumptions of the model are that (1) flow is steady, (2) flow is incompressible, (3) flow is hydrostatic (vertical accelerations are neglected), and (4) turbulence is adequately treated by relating Reynolds stresses to shear using an isotropic eddy viscosity. Minimum data requirements for the model include channel geometry, streamflow at the upstream boundary, and water-surface elevation at the downstream boundary.

The model drag coefficient represents the roughness of the river bottom and banks; this roughness is attributable to the combined effects of channel topography, bedforms, bars, vegetation, and sediment on the riverbed. In this study, the drag coefficient was given a uniform value throughout an entire reach by empirically calibrating the model so the simulated water surface elevation drop matched the measured values. This calibration ensures that the selected drag coefficient adequately represents the total head loss along the river reach. Other choices for drag incorporating spatially distributed values may produce simulations that are more accurate, but require more detailed information (including spatial distributions of grain size, bedforms and their evolution over changing streamflows, and other physical characteristics of the channel bed and banks) than currently is available.
The river channel geometry in the braided-straight reach model and meander-straight model was defined by bathymetry measurements and by Light Detection and Ranging (LIDAR) measurements. Vertical datum for the bathymetry and LIDAR measurement was referenced to the North American Vertical Datum of 1988 (NAVD 88). Horizontal coordinate information for the bathymetry and LIDAR measurement was referenced to the North American Datum of 1983 (NAD 83), Idaho Transverse Mercator-North American Datum 1983/1998 Idaho West, in meters.

\section{Bathymetry and Streambank Topography}

A brief summary of the bathymetric mapping is provided here and a complete description is contained in reports by Barton and others $(2004,2005)$. Bathymetric data were obtained by the USGS by connecting real-time Global Positioning System (GPS) equipment with survey-grade echo sounders. Taking into account all sources of mapping error, the bathymetry was mapped with a horizontal accuracy of $\pm 0.05 \mathrm{~m}$ and a vertical accuracy of $\pm 0.1 \mathrm{~m}$. During 2002, 2003, and 2005, the USGS measured water depth with a singlebeam echo sounder (Innerspace Technology, Inc., Model 448). Spacing between those cross sections between RKMs 227 and 245.9 ranged from less than 10 to about $50 \mathrm{~m}$. During 2004 and 2005, the USGS also measured water depth with a multichannel echo sounder (Ross Model 875-4 with four channels). Spacing between each of the four sounding transducers was $2.8 \mathrm{~m}$. The multi-channel echo sounder was used to survey a series of longitudinal lines between RKMs 236.8 and 245.9 and between RKMs 222.2 and 232.0. These longitudinal lines generally were parallel and spaced less than $5 \mathrm{~m}$ in the straight and meander reaches. The single- and multi-channel echo sounders also were used to survey longitudinal lines in the braided reach between RKMs 245.9 and 254. Survey line in the braided reach are spaced farther apart than in the straight and meander reach due to shallow water depth and high streamflow velocity that affected navigation of the survey vessel. Spacing between longitudinal lines of bathymetric data ranged from 2.8 to about $10 \mathrm{~m}$. Bathymetry was mapped with greater coverage where river depth was more variable. Where the bottom was relatively uniform, less bathymetric data were needed to characterize the slope of the channel. The bathymetry data were interpolated between mapped elevations to provide a more continuous coverage. A LIDAR survey was done throughout the Kootenai River Valley in Idaho during spring 2005 when streamflow was $340 \mathrm{~m}^{3} / \mathrm{s}$. A contractor for KTOI surveyed the valley floor, floodplain, and the channel to the edge of water. The survey data were provided to the USGS as a 1-m digital elevation model. 


\section{Streamflow}

Selection of historical streamflow conditions used for model calibration was based on two criteria: (1) streamflows should be evenly distributed between low flow (less than $226 \mathrm{~m}^{3} / \mathrm{s}$ ) and the pre-Libby Dam era median annual flood $\left(2,240 \mathrm{~m}^{3} / \mathrm{s}\right)$ so the model could be adequately calibrated over the range of streamflow in the river; and (2) because MD_SWMS was used as a steady-state model, calibration conditions were selected that represented periods of relatively constant water-surface elevation and discharge during periods of relatively constant stage and discharge. Criterion (1) was met for the meander-straight reach model; however, the braided-straight reach model was calibrated to a streamflow slightly less than $2,000 \mathrm{~m}^{3} / \mathrm{s}$ due to a shorter period of record for stage and streamflow measurements.

During model runs, including calibration for the braidedstraight reach model and meander-straight reach model, channel curvature at the downstream model boundary caused recirculation currents at the model boundary. To address this common problem, the MD_SWMS grid extension module was used to extend and gradually straighten the grid in the downstream direction by 100 nodes over a distance of $1,000 \mathrm{~m}$ to eliminate recirculation regions at the downstream end of the model reach. The grid extension did not alter the streamflow solution in the region of interest.

\section{Braided-Straight Reach Multidimensional Flow Model}

The computational grid used to model the braidedstraight reach of the Kootenai River was 8,200 m long with 985 nodes in the downstream direction and 1,300 $\mathrm{m}$ wide with 131 nodes in the cross-stream direction, forming an approximately $10 \times 10$-m cell (fig. 4). Measured bathymetric and LIDAR elevation data for the braided-straight model was mapped to the computation grid through a "nearest-neighbor" method, as described by Barton and others (2005, p. 20).

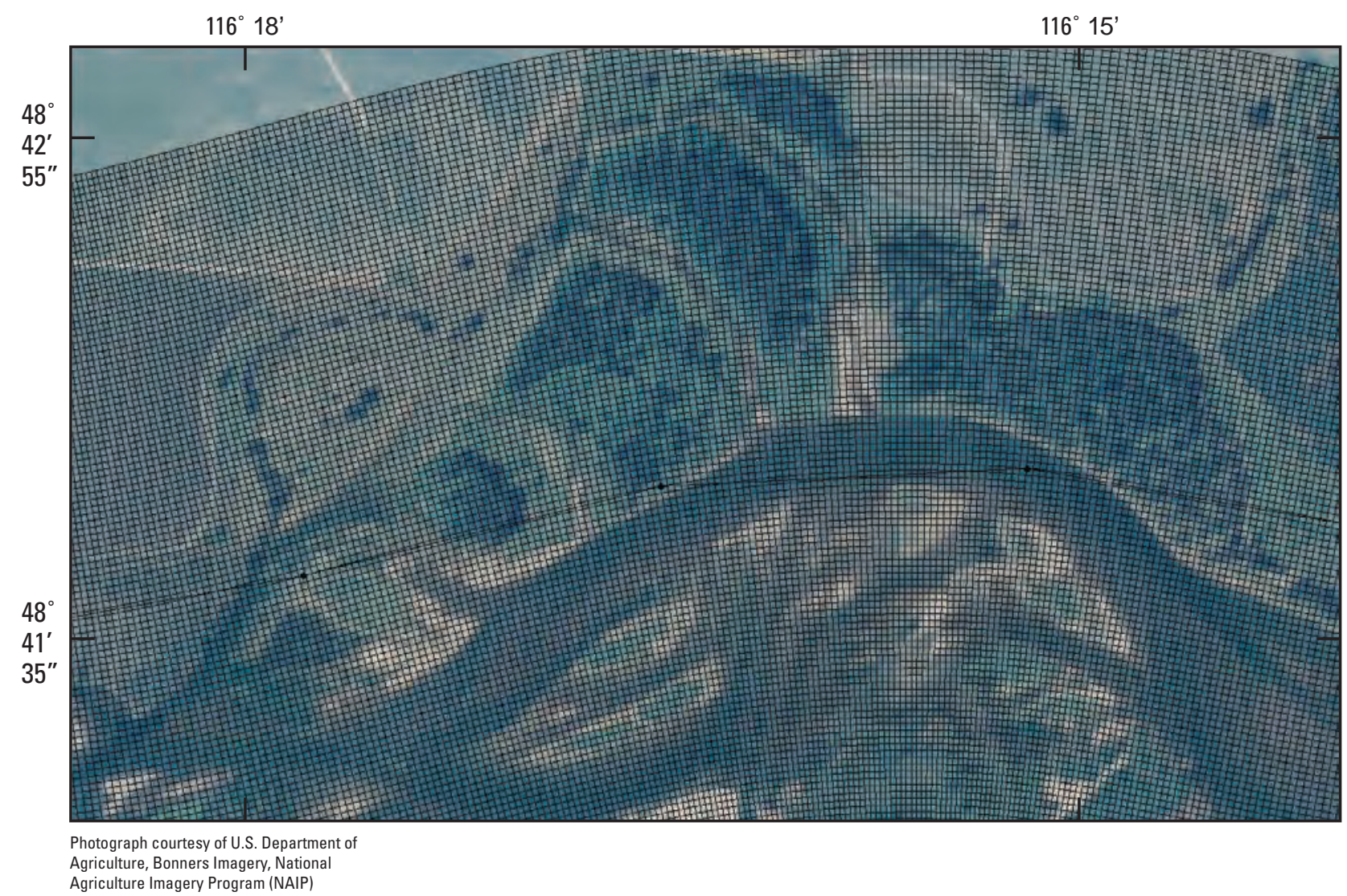

Figure 4. Nodes forming an approximately 10 by 10 -meter grid in the multidimensional flow model at river kilometer 247.3 to 249.3 in the braided reach of the Kootenai River near Bonners Ferry, Idaho. 


\section{Model Calibration}

The model was calibrated to eight streamflow conditions during 2006 (table 1) that ranged from 196 to $1,760 \mathrm{~m}^{3} / \mathrm{s}$ (fig. 5). During April 2006, temporary stage gaging stations were installed at five locations in the braided reach (fig. 2). These gaging stations, in addition to the Bonners Ferry (12309500) stage gaging station and Tribal Hatchery (12310100) stage and discharge gaging station, recorded stage in 15-minute intervals and provided important data for model calibration.
In addition to streamflow rates, water-surface elevations at the downstream boundary of the model are required to run FaSTMECH. For five streamflows the water-surface elevation at the downstream boundary of the model was interpolated from gaging stations 12314000 and 12310100 (fig. 2). For three streamflows the water-surface elevation was interpolated from synoptic water-surface elevation measurement (table 1).

The calibration process involved repeatedly adjusting the drag coefficient within reasonable limits to minimize the difference between the measured and simulated water-surface

Table 1. Calibration summary for the multidimensional flow model for the braided-straight reach of the Kootenai River near Bonners Ferry, Idaho, 2006.

[Streamflow for model calibration: A range of flows was selected from the 2005 and 2006 hydrograph with each flow representing the greatest duration of steady streamflow, less than a 5 percent change in flow within 24 hours. Streamflow is from the USGS Tribal hatchery gaging station 12310100. Computed water-surface elevation: water-surface elevations for five streamflows were obtained from two permanent and five temporary stage gaging stations in the model reach and water-surface elevations for three calibration flows were made by a synoptic water-surface elevation measurement. The model is constructed with a uniform drag coefficient. Simulated average depth and velocity, as well as computed lateral eddy viscosity, are based on the population of all wet nodes in the model. Abbreviations: $\mathrm{ft}$, foot; $\mathrm{ft}^{3} / \mathrm{s}$, cubic foot per second; $\mathrm{ft} / \mathrm{s}$, foot per second; $\mathrm{m}^{3} / \mathrm{s}$, cubic meter per second; $\mathrm{m}$, meter; $\mathrm{m}^{2} / \mathrm{s}$, meter squared per second; $\mathrm{m} / \mathrm{s}$, meter per second; GPS, Global Positioning System; RMS, root mean square; USGS, U.S. Geological Survey]

\begin{tabular}{|c|c|c|c|c|c|c|c|c|c|c|c|}
\hline \multirow{3}{*}{ Date } & \multirow{3}{*}{ Time } & \multirow{2}{*}{\multicolumn{2}{|c|}{$\begin{array}{c}\text { Streamflow for } \\
\text { model calibration }\end{array}$}} & \multirow{3}{*}{$\begin{array}{l}\text { Computed } \\
\text { water- } \\
\text { surface } \\
\text { slope }\end{array}$} & \multicolumn{4}{|c|}{$\begin{array}{c}\text { Computed water-surface elevation } \\
\text { at model boundaries }\end{array}$} & \multirow{3}{*}{\multicolumn{3}{|c|}{$\begin{array}{l}\text { Average measured } \\
\text { stage minus average } \\
\text { simulated stage at } \\
\text { seven gaging stations } \\
\text { along the model } \\
\text { reach }(\mathrm{m})\end{array}$}} \\
\hline & & & & & \multicolumn{2}{|c|}{ Downstream } & \multicolumn{2}{|c|}{ Upstream } & & & \\
\hline & & $\mathrm{m}^{3} / \mathrm{s}$ & $\mathrm{ft}^{3} / \mathrm{s}$ & & $(\mathrm{m})$ & $(\mathrm{ft})$ & $(\mathrm{m})$ & $(\mathbf{f t})$ & & & \\
\hline${ }^{1} 03-01-06$ & 01:00 PM & 196 & 6,930 & 0.0005 & 532.80 & $1,748.04$ & 537.55 & $1,763.62$ & & 0.003 & \\
\hline${ }^{2} 04-26-06$ & 11:00 AM & 380 & 13,400 & .0005 & 533.71 & $1,751.02$ & 538.52 & $1,766.81$ & & .002 & \\
\hline${ }^{107-20-06}$ & 03:45 PM & 511 & 19,600 & .0005 & 535.00 & $1,755.53$ & 539.00 & $1,768.37$ & & -.018 & \\
\hline${ }^{1} 06-28-06$ & 02:15 PM & 813 & 29,300 & .0004 & 536.16 & $1,759.06$ & 539.85 & $1,771.16$ & & .007 & \\
\hline${ }^{2} 05-30-06$ & 11:00 PM & 983 & 34,700 & .0003 & 537.45 & $1,763.29$ & 540.00 & $1,771.65$ & & .003 & \\
\hline${ }^{2} 05-22-06$ & 11:00 AM & 1,310 & 46,300 & .0002 & 538.34 & $1,766.22$ & 540.66 & $1,773.82$ & & .012 & \\
\hline${ }^{2} 06-21-06$ & 02:00 PM & 1,630 & 57,500 & .0002 & 539.17 & $1,768.94$ & 540.80 & $1,774.29$ & & .009 & \\
\hline${ }^{2} 06-18-06$ & 02:00 PM & 1,760 & 62,100 & .0002 & 539.46 & $1,769.89$ & 541.60 & $1,776.91$ & & .008 & \\
\hline \multirow[t]{2}{*}{ Date } & \multirow[t]{2}{*}{ Time } & \multirow{2}{*}{\multicolumn{2}{|c|}{$\begin{array}{l}\text { RMS error calculated } \\
\text { for measured and } \\
\text { simulated stage }\end{array}$}} & \multirow{2}{*}{\multicolumn{2}{|c|}{$\begin{array}{c}\text { Model drag } \\
\text { coefficient } \\
\text { (dimensionless) }\end{array}$}} & \multicolumn{2}{|c|}{$\begin{array}{c}\text { Lateral eddy } \\
\text { viscosity }\left(\mathrm{m}^{2} / \mathrm{s}\right)\end{array}$} & \multicolumn{2}{|c|}{$\begin{array}{l}\text { Simulated } \\
\text { average } \\
\text { river depth }\end{array}$} & \multicolumn{2}{|c|}{$\begin{array}{l}\text { Simulated } \\
\text { average } \\
\text { streamflow } \\
\text { velocity }\end{array}$} \\
\hline & & & & & & Model & Computed & $(\mathrm{m})$ & (ft) & $(\mathrm{m} / \mathrm{s})$ & $(\mathrm{ft} / \mathrm{s})$ \\
\hline${ }^{1} 03-01-06$ & 01:00 PM & \multicolumn{2}{|r|}{0.089} & \multicolumn{2}{|c|}{0.0024} & 0.014 & 0.014 & 2.3 & 7.5 & 0.610 & 2.01 \\
\hline${ }^{2} 04-26-06$ & 11:00 AM & \multicolumn{2}{|r|}{.111} & \multicolumn{2}{|c|}{.0024} & .019 & .019 & 2.4 & 7.8 & .780 & 2.57 \\
\hline${ }^{1} 07-20-06$ & 03:45 PM & \multicolumn{2}{|r|}{.002} & \multicolumn{2}{|c|}{.0024} & .025 & .025 & 2.6 & 8.7 & .940 & 3.07 \\
\hline${ }^{1} 06-28-06$ & 02:15 PM & \multicolumn{2}{|r|}{.114} & \multicolumn{2}{|c|}{.0025} & .032 & .032 & 3.3 & 10.8 & .950 & 3.13 \\
\hline${ }^{2} 05-30-06$ & 11:00 PM & \multicolumn{2}{|r|}{.049} & \multicolumn{2}{|c|}{.0029} & .034 & .034 & 3.9 & 12.8 & .870 & 2.84 \\
\hline${ }^{2} 05-22-06$ & 11:00 AM & \multicolumn{2}{|r|}{.034} & \multicolumn{2}{|c|}{.0029} & .042 & .042 & 4.5 & 14.8 & .938 & 3.08 \\
\hline${ }^{2} 06-21-06$ & 02:00 PM & \multicolumn{2}{|r|}{.037} & \multicolumn{2}{|c|}{.0030} & .049 & .049 & 5.2 & 17.0 & .936 & 3.07 \\
\hline${ }^{2} 06-18-06$ & 02:00 PM & \multicolumn{2}{|r|}{.034} & \multicolumn{2}{|c|}{.0032} & .051 & .051 & 5.4 & 17.9 & .943 & 3.09 \\
\hline
\end{tabular}

${ }^{1}$ Synoptic water-surface elevation measured by survey-grade global positioning system.

${ }^{2}$ Synoptic water-surface elevation measured at seven gaging stations. 
elevations. In addition the model-user must input a lateral eddy viscosity (LEV) to represent lateral momentum exchange due to turbulence or other variability not generated at the bed (Nelson and others, 2003). The lateral eddy viscosity parameter for the model was computed and iteratively applied to the calibration for each streamflow condition using equation 1 defined as:

$$
\mathrm{LEV}=0.01 * u_{\text {avg }} * y_{\text {avg }},
$$

where

LEV is lateral eddy-viscosity coefficient, in square meters per second,

$u_{\text {avg }}$ is average velocity, in meters per second, and

$y_{\text {avg }}$ is average depth, in meters.
The computed LEV value was applied uniformly throughout the modeling reach for each calibration streamflow. LEV consistently increased with increasing streamflow (fig. 5) from 196 to $1,760 \mathrm{~m}^{3} / \mathrm{s}$ and ranged from 0.014 to 0.051 , respectively.

The resulting calibration shows that the drag coefficient increases from approximately 0.0024 at flows less than $500 \mathrm{~m}^{3} / \mathrm{s}$ to approximately 0.003 at flows greater than $1,000 \mathrm{~m}^{3} / \mathrm{s}$. This step-change increase in the drag coefficient occurs as the river stage increases and overtops the vegetated bars in the braided reach. The difference between the simulated and measured water-surface elevations was less than or equal to $\pm 0.03 \mathrm{~m}$.

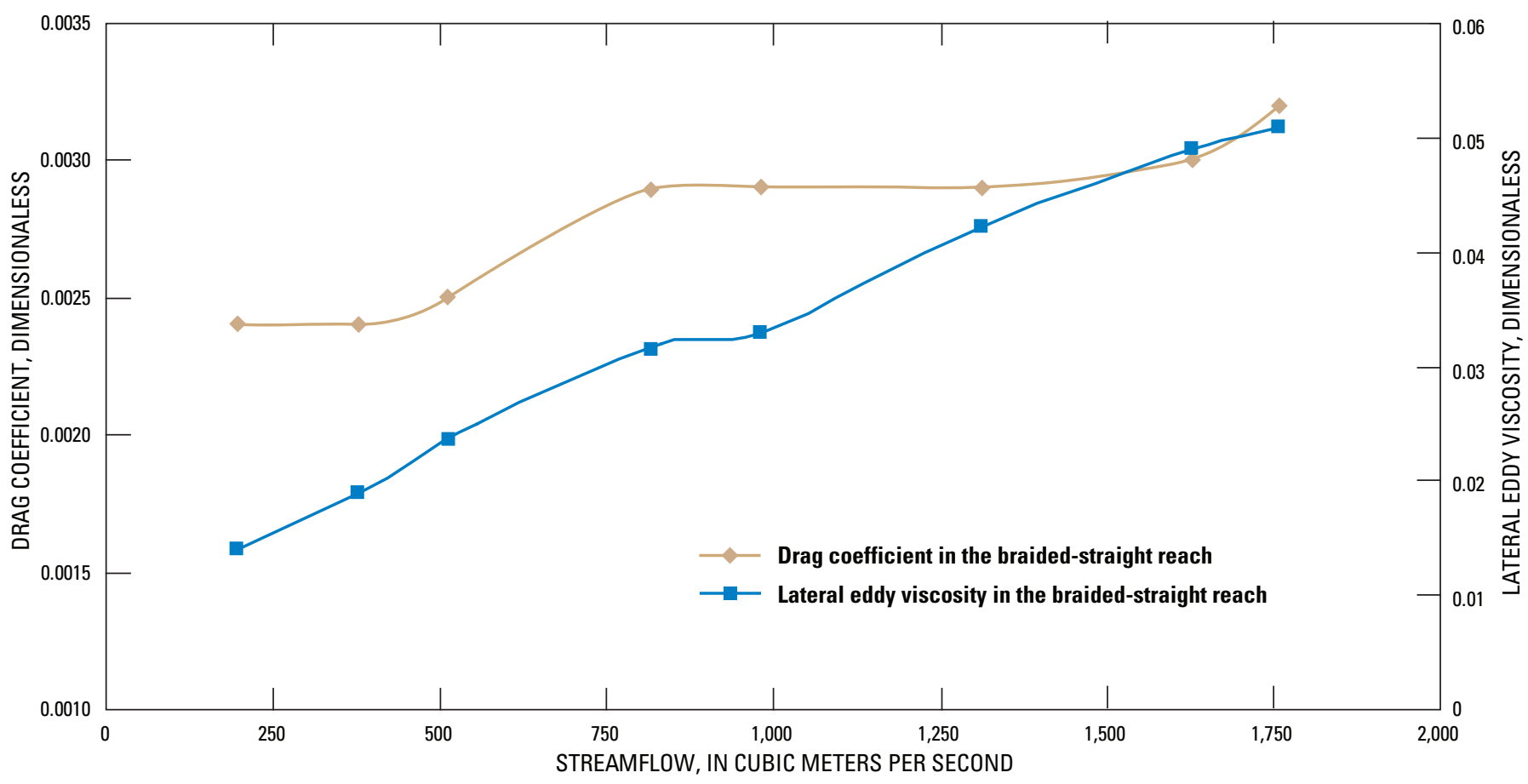

Figure 5. Drag coefficient and lateral eddy viscosity for the calibrated braided-straight reach multidimensional flow model, Kootenai River near Bonners Ferry, Idaho. 


\section{Model Validation}

The braided-straight reach model was validated by comparing simulated streamflow velocities with streamflow velocities measured at five cross sections between RKMs 246.1 and 251.5 (fig. 2) during relatively steady streamflow that ranged between 826 and $860 \mathrm{~m}^{3} / \mathrm{s}$ on May 25-26, 2005 . Streamflow velocities were measured using an acoustic Doppler current profiler (ADCP) that was connected to a Trimble mapping-grade GPS receiver and Fugawi navigational software. Streamflow velocity at five cross sections was measured multiple (5-10) times to obtain average velocities suitable for comparison to the model simulation results. Measured data were processed into vertically averaged cross section velocity to test the two-dimensional model component. A general description of procedures for processing raw ADCP data are available in Dinehart (2003) and Barton and others (2005).
The braided-straight reach model simulates the magnitude and structure of flow across the section reasonably well (fig. 6). However, small differences were noted between the measured and simulated velocities in most cross-sections. Several possible reasons can explain the mismatch between simulated and measured velocities throughout the study reach. The complex channel topography, particularly upstream of sections 2467 and 2482, resulted in as many as four separate velocity threads across the channel. Subtle differences between simulated topography and actual topography can lead to differences in the routing of streamflow between each of these four channels and therefore differences in the velocity in each channel. Additionally, specifying a constant drag coefficient throughout the reach does not account for vegetation on the surface of the bars separating each channel thread. The high roughness of the vegetated bars relative to the grain roughness of the channel likely exerts an additional influence on the routing of streamflow into each of the four channel threads and therefore on the velocity distribution across the channel downstream. 
APPROXIMATE

LOCATION OF

LEFT BANK
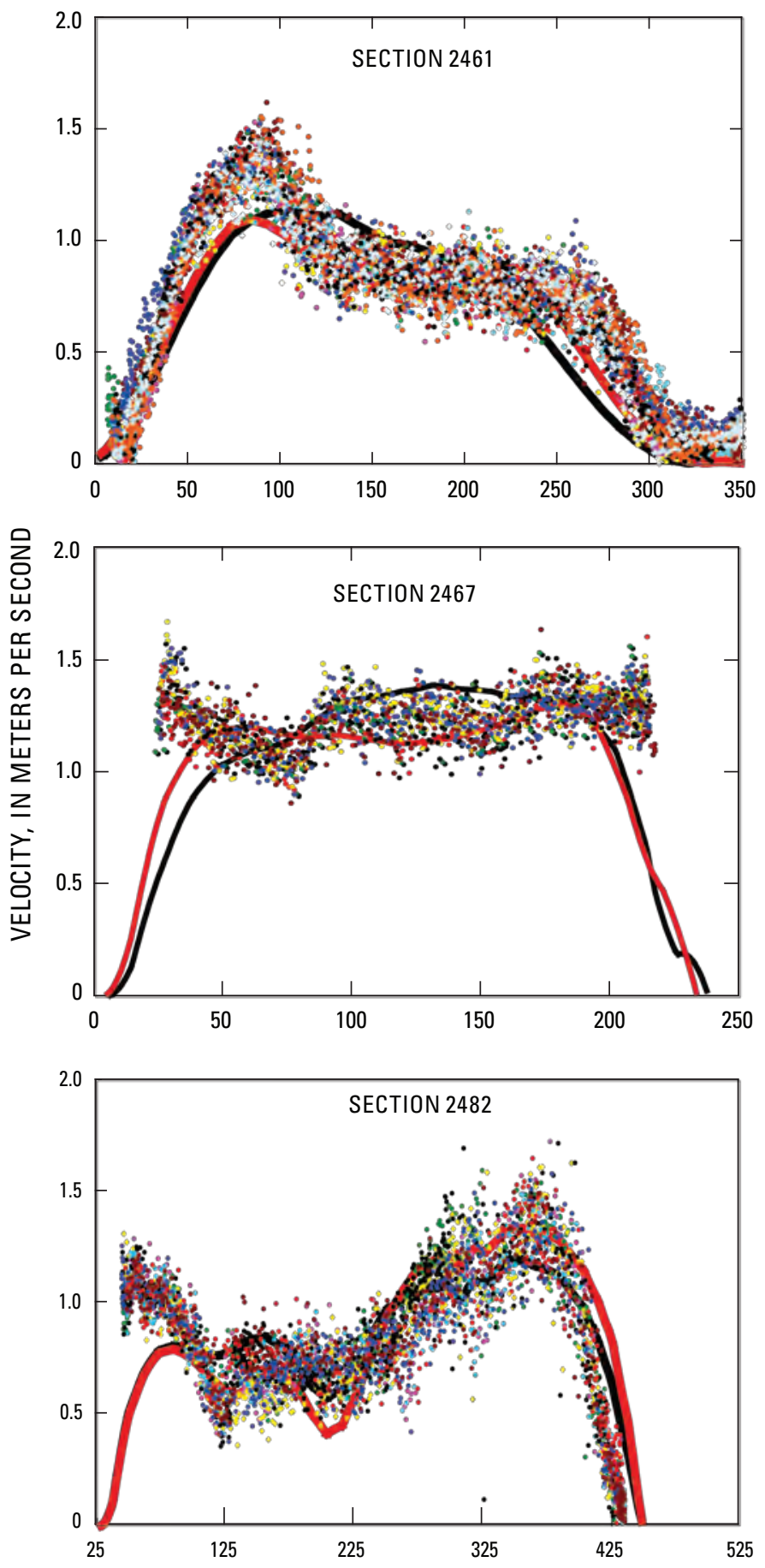

DISTANCE FROM LEFT BANK, IN METERS
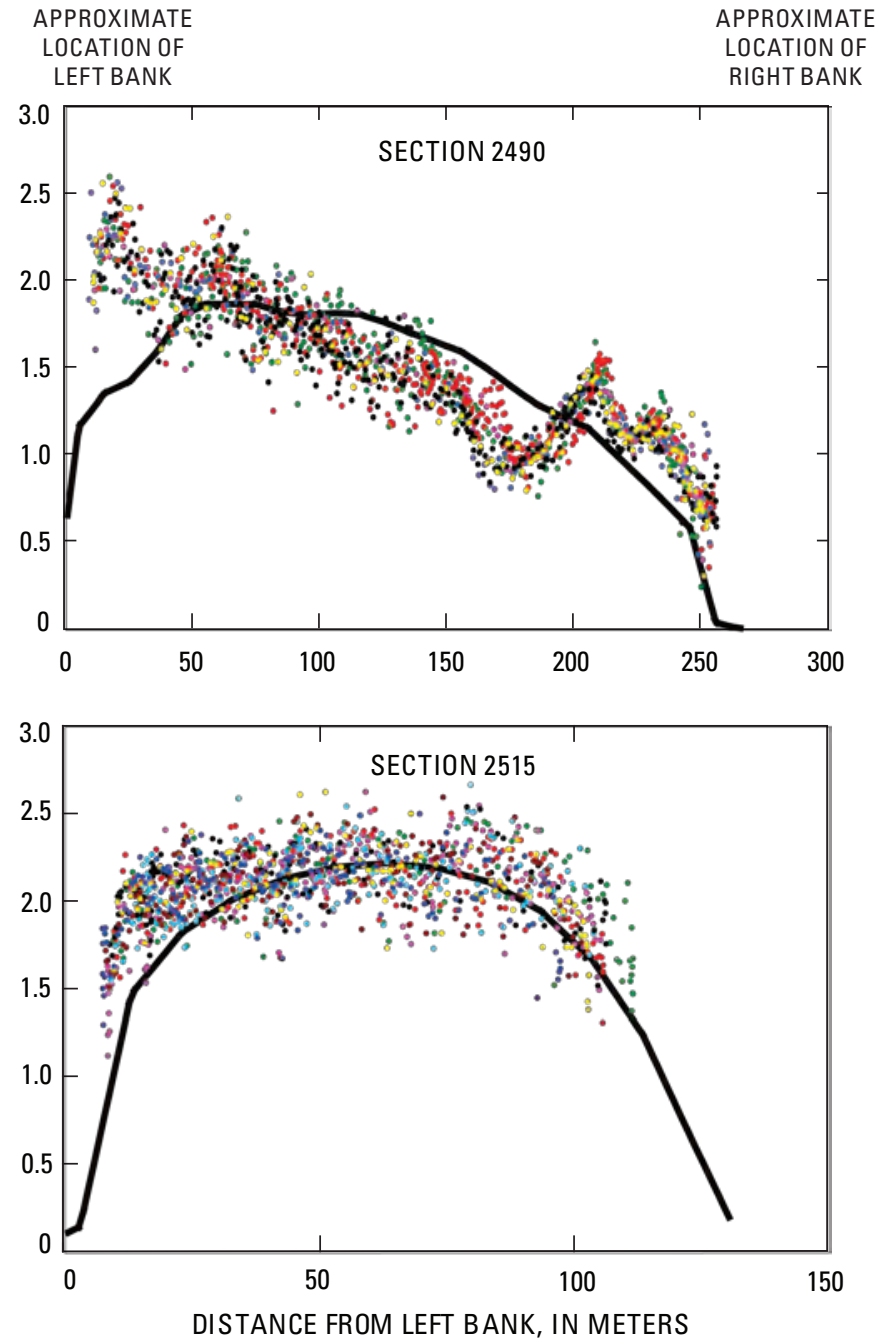

\section{EXPLANATION}

\section{Simulated velocity with variable drag coefficient}

Each color represents a vertically averaged velocity cross section calculated from a single pass of an accoustic Doppler current profiler (ADCP) across the channel. Each cross section was measured multiple (5-10) times with the ADCP

Figure 6. Measured cross sections of vertically averaged velocities and corresponding simulated velocities in the braided reach, for streamflow ranging from 825 to 860 cubic meters per second, Kootenai River near Bonners Ferry, Idaho, May 25-26, 2005. 
To illustrate the effect of vegetation roughness on the model simulated velocity the tops of bars were approximately mapped as seen in a series of aerial photographs taken in 2002 (fig. 7). To simulate the relatively high roughness of the vegetated bar tops we partitioned the reach using two drag coefficients. The drag coefficient for the most of the model was set to the calibrated value and the bar top drag coefficient was set to a significantly higher value of 0.1 . The resulting simulated velocities are shown in figure 6 for sections 2461, 2467, and 2482. A comparison between the measured and simulated velocities using both a uniform drag coefficient and a variable drag coefficient (fig. 6) indicates that the model simulation results could be improved through a better understanding of the effect of vegetation on channel roughness. Proper calibration of the model to vegetation roughness would require measured velocities over the entire modeled range of streamflows because the effect of vegetation on roughness varies with vegetation type and degree of inundation (Wu and others, 1999). Using a simple uniform value of roughness for the entire modeled reach captures the salient features of the measured velocity.

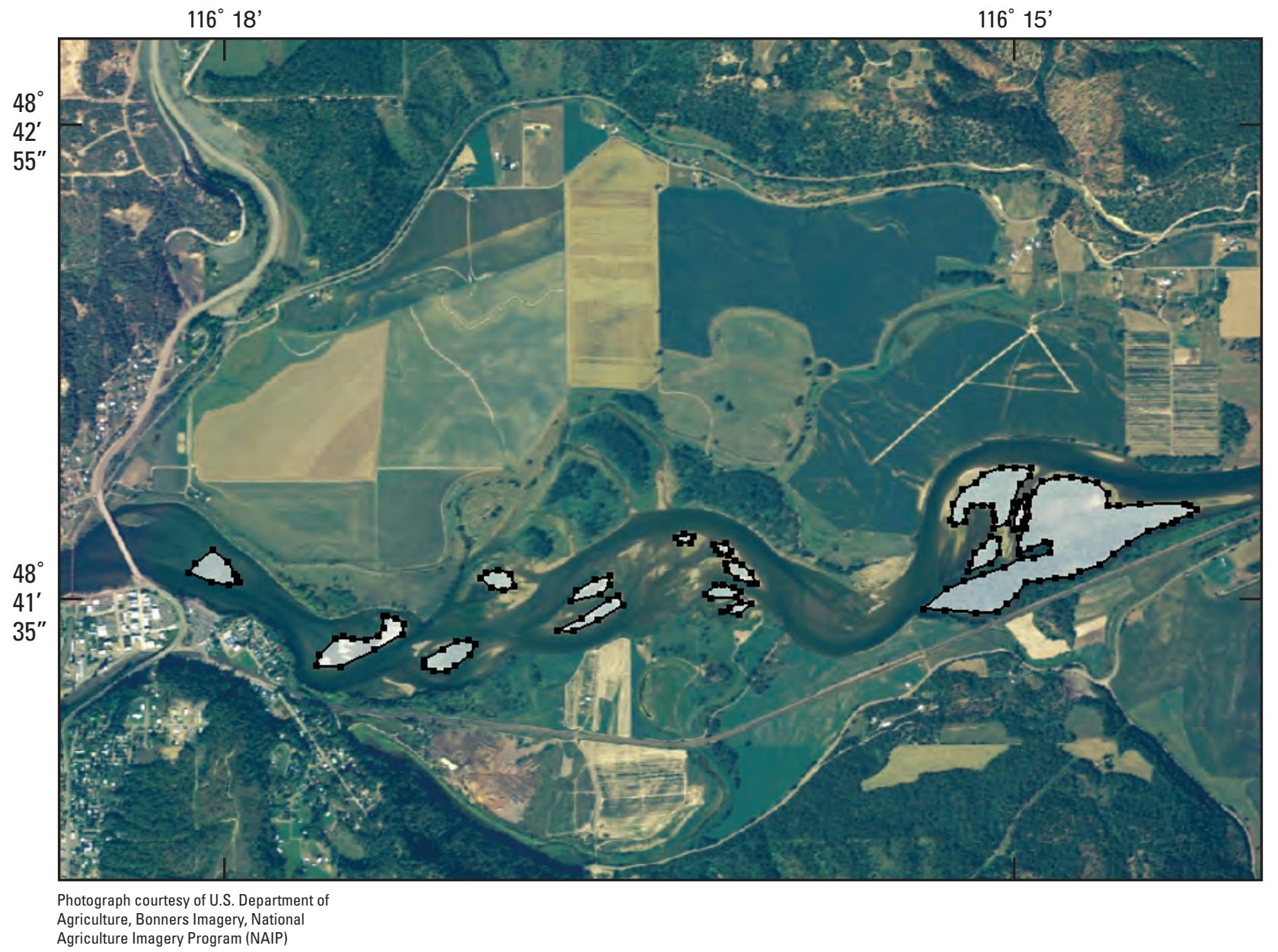

Figure 7. Gravel bars in the braided reach and polygons representing locations where variable drag coefficients were applied in the braided-straight reach model, Kootenai River near Bonners Ferry, Idaho, 2002. 


\section{Model Sensitivity Analysis}

Sensitivity analysis of the braided-straight reach model consisted of decreasing and increasing the calibrated drag coefficient by 85 and 115 percent during streamflow simulation runs of $170,1,130$, and $2,120 \mathrm{~m}^{3} / \mathrm{s}$. The analysis includes reporting median and maximum river water-surface elevation and velocity for the entire population of wet model nodes (table 2). Varying calibrated drag coefficient by 85 and 115 percent changed the median water-surface elevation by 0.01 to $0.15 \mathrm{~m}$ and the median velocities by 0.01 to $0.03 \mathrm{~m} / \mathrm{s}$, respectively.

\section{Meander-Straight Reach Multidimensional Flow Model}

The computational grid used in the Kootenai River meander-straight reach model was $23,600 \mathrm{~m}$ long with 2,359 nodes in the downstream direction and $725 \mathrm{~m}$ wide with 73 nodes in the cross-stream direction, forming an approximately $10 \times 10$-m grid. Measured bathymetric and LIDAR data, for the meander-straight reach model was mapped to the computation grid through a "nearest-neighbor" method. Procedures for mapping topography to the grid are the same as described in Barton and others (2005) except that a $10 \times 10$-m grid rather than a $5 \times 5$-m grid was used.

Magnitude and direction of streamflow-velocity vectors at the upstream boundary of the model grid had a significant effect on the simulated streamflow patterns for roughly the upper few channel widths of the modeled reach. Uncertainty in model simulation results near the upstream boundary is common in many models. Velocity magnitude and direction were specified at the upstream boundary using the same conditions as the previous model by Barton and others (2005). These streamflow-velocity conditions were based on streamflow measurements made at a cross section at RKM 245.9 for streamflows of $1,260 \mathrm{~m}^{3} / \mathrm{s}$ measured June 7, 1996, and $776 \mathrm{~m}^{3} / \mathrm{s}$ measured April 16, 2002.

Table 2. Sensitivity analysis and results of the multidimensional flow model streamflow simulations for the braidedstraight reach, Kootenai River near Bonners Ferry, Idaho.

\begin{tabular}{|c|c|c|c|c|c|c|c|c|c|c|c|c|c|c|}
\hline \multicolumn{2}{|c|}{$\begin{array}{c}\text { Streamflow for river } \\
\text { model simulation }\end{array}$} & \multirow{3}{*}{$\begin{array}{c}\text { Drag } \\
\text { coefficient }\end{array}$} & \multicolumn{4}{|c|}{ Depth } & \multicolumn{4}{|c|}{ Velocity } & \multicolumn{4}{|c|}{ Water-surface elevation } \\
\hline \multirow{2}{*}{$\mathrm{m}^{3} / \mathrm{s}$} & \multirow{2}{*}{$\mathrm{ft}^{3} / \mathrm{s}$} & & \multicolumn{2}{|c|}{ (m) } & \multicolumn{2}{|c|}{ (ft) } & \multicolumn{2}{|c|}{$(\mathrm{m} / \mathrm{s})$} & \multicolumn{2}{|c|}{$(\mathrm{ft} / \mathrm{s})$} & \multicolumn{2}{|c|}{ (m) } & \multicolumn{2}{|c|}{ (ft) } \\
\hline & & & Med. & Max. & Med. & Max. & Med. & Max. & Med. & Max. & Med. & Max. & Med. & Max. \\
\hline \multirow[t]{3}{*}{170} & 6,000 & 0.0024 & 1.41 & 19.75 & 4.63 & 64.81 & 0.42 & 2.34 & 1.38 & 7.68 & 534.80 & 539.24 & $1,754.68$ & $1,769.25$ \\
\hline & & .0020 & 1.40 & 19.75 & 4.59 & 64.80 & .43 & 2.57 & 1.41 & 8.43 & 534.78 & 539.22 & $1,754.61$ & $1,769.18$ \\
\hline & & .0028 & 1.42 & 19.76 & 4.66 & 64.83 & .41 & 2.31 & 1.36 & 7.59 & 534.81 & 539.26 & $1,754.71$ & $1,769.31$ \\
\hline 566 & 20,000 & .0025 & 2.08 & 21.78 & 6.81 & 71.47 & .91 & 2.74 & 2.97 & 8.99 & 535.67 & 539.80 & $1,757.53$ & $1,771.08$ \\
\hline \multirow[t]{3}{*}{1,130} & 40,000 & .0029 & 3.35 & 23.85 & 10.98 & 78.26 & .97 & 3.04 & 3.18 & 9.98 & 537.41 & 540.52 & $1,763.24$ & $1,773.45$ \\
\hline & & .0025 & 3.29 & 23.84 & 10.81 & 78.21 & 1.00 & 3.31 & 3.28 & 10.86 & 537.34 & 540.42 & $1,763.01$ & $1,773.12$ \\
\hline & & .0033 & 3.38 & 23.86 & 1109 & 78.29 & .96 & 2.90 & 3.13 & 9.52 & 537.46 & 540.59 & 1,763.41 & 1,773.68 \\
\hline 1,700 & 60,000 & .0031 & 4.90 & 26.07 & 16.09 & 85.53 & .98 & 3.08 & 3.23 & 10.10 & 539.49 & 541.86 & $1,770.07$ & $1,777.84$ \\
\hline \multirow[t]{3}{*}{2,120} & 75,000 & .0032 & 5.83 & 27.10 & 18.99 & 88.88 & 1.00 & 3.31 & 3.29 & 10.88 & 540.56 & 542.66 & $1,773.58$ & $1,780.47$ \\
\hline & & .0027 & 5.79 & 27.09 & 19.13 & 88.91 & 1.02 & 3.37 & 3.33 & 11.06 & 540.51 & 542.59 & $1,773.41$ & $1,780.24$ \\
\hline & & .0037 & 5.89 & 27.11 & 19.31 & 88.95 & .99 & 3.24 & 3.25 & 10.64 & 540.71 & 54276 & $1,774.07$ & $1,780.80$ \\
\hline
\end{tabular}




\section{Model Calibration}

The meander-straight reach model was subdivided into two regions of uniform drag coefficients to improve calibration for streamflows less than $1,420 \mathrm{~m}^{3} / \mathrm{s}$. One uniform value of drag coefficient was applied to the straight reach and a separate value was applied to the meander reach. These two regions of uniform drag coefficients are necessary because upstream model boundary conditions cause model convergence problems in the relatively short straight reach.

The model was calibrated to nine streamflow conditions (table 3) ranging from 170 to $2,120 \mathrm{~m}^{3} / \mathrm{s}$. Water-surface elevation at the downstream model boundary were set using a one-dimensional model (Berenbrock, 2005). A complete description of these conditions is available in a report by Berenbrock (2006). Calibration for each streamflow condition consisted of comparing simulated water-surface elevations in the meander reach model and the simulated watersurface elevations at 37 sites from Berenbrock (2006). This process involved repeatedly adjusting the drag coefficient within reasonable limits, running the model, and inspecting differences between simulated water-surface elevations and Berenbrock's one-dimensional model water-surface elevations with the objective of minimizing the difference. Differences in calibrated meander-straight reach model-simulated watersurface elevations and Berenbrock's one-dimensional model water-surface elevations were less than or equal to $\pm 0.02 \mathrm{~m}$.

Table 3. Calibration summary for the multidimensional flow model for the meander-straight reach, Kootenai River near Bonners Ferry, Idaho.

Streamflow for river model simulation: The model is constructed with a variable drag coefficient for the 170,566 , and $1,130 \mathrm{~m}^{3} / \mathrm{s}$ streamflow management scenarios. A drag coefficient is specified for the reach between the upstream boundary of the model and Ambush Rock and a different drag coefficient is specified for the reach between Ambush Rock and the downstream boundary of the model. Computed water-surface elevations: Water-surface elevations for objective calibration flows correspond to median water-surface elevations at the Queens Bay gaging station in Kootenay Lake, British Columbia, Canada, and were computed using a 1-dimensional flow model (Berenbrock, 2005). Reported average river depth and streamflow velocity values are based on the population of all wet nodes in the model. Abbreviations: $\mathrm{m}^{3} / \mathrm{s}$, cubic meter per second; $\mathrm{ft}^{3} / \mathrm{s}$, cubic foot per second; $\mathrm{m}$, meter; $\mathrm{ft}$, foot; $\mathrm{m}^{2} / \mathrm{s}$, $\mathrm{meter} \mathrm{squared}$ per second; $\mathrm{m} / \mathrm{s}$, meter per second; ft/s, foot per second; RMS, root mean square]

\begin{tabular}{|c|c|c|c|c|c|c|c|c|c|c|c|}
\hline \multirow{2}{*}{\multicolumn{2}{|c|}{$\begin{array}{l}\text { Streamflow for } \\
\text { river model } \\
\text { simulation }\end{array}$}} & \multirow{3}{*}{$\begin{array}{l}\text { Computed } \\
\text { surface-water } \\
\text { slope }\end{array}$} & \multicolumn{4}{|c|}{$\begin{array}{c}\text { Computed water-surface elevation } \\
\text { at model boundaries }\end{array}$} & \multirow{3}{*}{\multicolumn{3}{|c|}{$\begin{array}{l}\text { Computed average } \\
\text { stage minus } \\
\text { simulated average } \\
\text { stage at thirty seven } \\
\text { stations along } \\
\text { the model reach (m) }\end{array}$}} & \multirow{3}{*}{\multicolumn{2}{|c|}{$\begin{array}{l}\text { RMS error for } \\
\text { measured and } \\
\text { simulated stage } \\
\text { at thirty seven } \\
\text { stations along } \\
\text { the model reach }\end{array}$}} \\
\hline & & & \multicolumn{2}{|c|}{ Downstream } & \multicolumn{2}{|c|}{ Upstream } & & & & & \\
\hline$\left(\mathrm{m}^{3} / \mathrm{s}\right)$ & $\left(\mathrm{ft}^{3} / \mathrm{s}\right)$ & & (m) & (ft) & (m) & (ft) & & & & & \\
\hline 170 & 6,000 & 0.00003 & 532.62 & $1,747.54$ & 533.25 & $1,749.5$ & & 0.01 & & & 18 \\
\hline 850 & 30,000 & .00004 & 535.16 & $1,755.86$ & 536.10 & $1,758.9$ & & .01 & & & 25 \\
\hline 1,130 & 40,000 & .00010 & 536.03 & $1,758.72$ & 536.96 & $1,761.7$ & & .01 & & & 23 \\
\hline 1,420 & 50,000 & .00004 & 536.88 & $1,761.51$ & 537.89 & $1,764.8$ & & .00 & & & 20 \\
\hline 1,700 & 60,000 & .00005 & 537.79 & $1,764.50$ & 538.90 & $1,768.1$ & & .00 & & & 24 \\
\hline 1,980 & 70,000 & .00005 & 538.74 & $1,767.60$ & 539.93 & $1,771.5$ & & .00 & & & 23 \\
\hline 2,120 & 75,000 & .00005 & 539.22 & $1,769.20$ & 540.44 & 1,773.2 & & .00 & & & 23 \\
\hline $\mathrm{m}^{3} / \mathrm{s}$ & $\mathrm{ft}^{3} / \mathrm{s}$ & $\begin{array}{r}\text { River kilon } \\
228.4 \text { to } 2 \\
\text { (meander-strai }\end{array}$ & $\begin{array}{l}\text { ter } \\
\text { t reach) }\end{array}$ & $\begin{array}{c}\text { River kilometer } \\
228.4 \text { to } 244.5 \\
\text { (meander reach) }\end{array}$ & $\begin{array}{c}\text { River kilometer } \\
244.5 \text { to } 245.8 \\
\text { (straight reach) }\end{array}$ & Model & Computed & $(\mathrm{m})$ & (ft) & $(\mathrm{m} / \mathrm{s})$ & $(\mathrm{ft} / \mathrm{s})$ \\
\hline 170 & 6,000 & - & & 0.0056 & 0.0131 & 0.011 & 0.011 & 4.6 & 15.1 & 0.24 & 0.8 \\
\hline 283 & 10,000 & - & & .0040 & .0073 & .017 & .017 & 5.0 & 16.4 & .34 & 1.1 \\
\hline 566 & 20,000 & - & & .0033 & .0057 & .030 & .030 & 5.8 & 19.0 & .52 & 1.7 \\
\hline 850 & 30,000 & - & & .0026 & .0041 & .044 & .044 & 6.6 & 21.7 & .66 & 2.2 \\
\hline 1,130 & 40,000 & - & & .0017 & .0030 & .055 & .055 & 7.3 & 24.0 & .76 & 2.5 \\
\hline 1,420 & 50,000 & 0.001 & & - & - & .066 & .066 & 7.9 & 25.9 & .84 & 2.8 \\
\hline 1,700 & 60,000 & 0.001 & & - & - & .079 & .079 & 8.8 & 28.9 & .90 & 3.0 \\
\hline
\end{tabular}


The ranges for drag coefficient values are similar to those from the study by Barton and others, (2005). Drag coefficients resulting from model calibration are shown in figure 8. For the straight reach between the RKM 245.9 and Ambush Rock, the drag coefficient decreased sharply from 0.0131 to 0.0073 as streamflow increased from 170 to $283 \mathrm{~m}^{3} / \mathrm{s}$. For streamflows greater than $1,130 \mathrm{~m}^{3} / \mathrm{s}$, no clear justification was established for using more than a single value of the drag coefficient, because model simulation results were not significantly improved using multiple values. Therefore, at greater streamflows, the drag coefficient was constant throughout the model simulation, increasing gradually from 0.0015 to 0.0019 as streamflow increased from 1,420 to $1,980 \mathrm{~m}^{3} / \mathrm{s}$, and then remaining about constant as streamflow increased to 2,120 $\mathrm{m}^{3} / \mathrm{s}$. As reported in Barton and others (2005), model calibration indicated that bedforms have a large effect on the drag coefficient at streamflows less than about $595 \mathrm{~m}^{3} / \mathrm{s}$ : channel roughness along the riverbed increases at low streamflows due to formation of tall dunes, and channel roughness decreases at higher streamflows because the dunes tend to wash out.

The model LEV parameter was computed for each model calibration condition using equation (1). The computed LEV value was applied uniformly throughout the model-simulated reach for each calibration streamflow. LEV consistently increased with increasing streamflow (fig. 8) and ranged from 0.011 to 0.095 for streamflow ranging from 170 to $2,120 \mathrm{~m}^{3} / \mathrm{s}$.

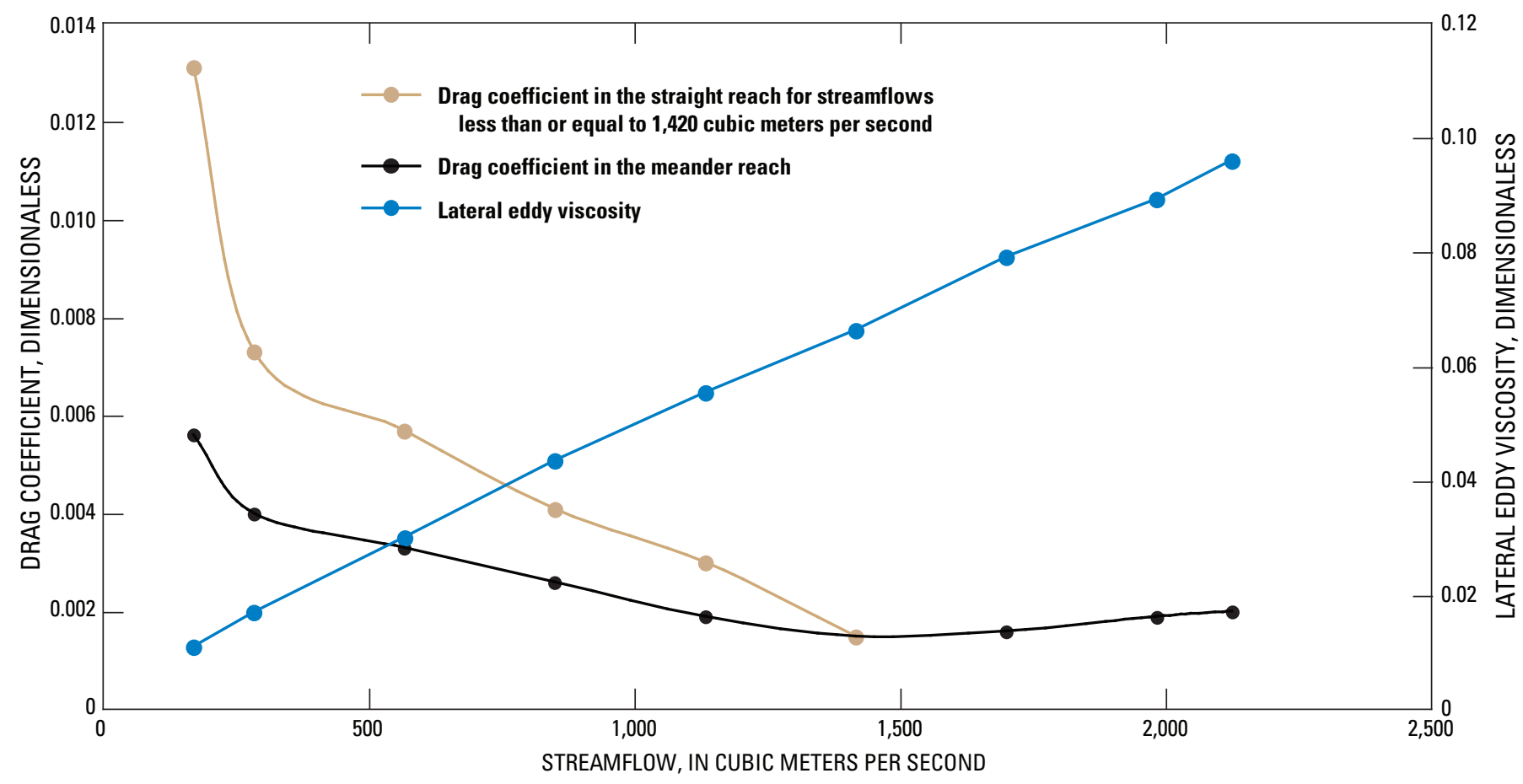

Figure 8. Drag coefficient and lateral eddy viscosity for the calibrated multidimensional flow model of the meanderstraight reach, Kootenai River near Bonners Ferry, Idaho. 


\section{Model Validation}

The previous multidimensional model of the meander and straight reaches (Barton and others, 2005) was validated by comparing simulated streamflow velocities with flow velocities measured at 15 cross sections between RKMs 229.1 and 236.9 during steady streamflow that averaged $538 \mathrm{~m}^{3} / \mathrm{s}$ on August 12-14, 2003. Details on model validation are available in Barton and others (2005). Validation of the new meanderstraight reach model was not required due to the similarity between the previous and new meander-straight reach models: (1) channel geometry in the 5.8 RKM downstream extension in the new model is comparable to the reach in the previous model, which had validation analysis, and (2) channel geometry data used in the downstream extension of the new model were collected with the same methodology as the previous model. Adding LIDAR data was considered an overall improvement to the meander-straight reach multidimensional model.

\section{Model Sensitivity Analysis}

Sensitivity analysis of the meander-straight reach multidimensional model consisted of decreasing and increasing the calibrated drag coefficient by 85 and 115 percent during streamflow simulation runs of $170,1,130$, and $2,120 \mathrm{~m}^{3} / \mathrm{s}$. The analysis included reporting median and maximum river depth, velocity, and water-surface elevation, for the entire population of wet model nodes (table 4). Varying calibrated drag coefficient by 85 and 115 percent changed the median water-surface elevation by 0.01 to $0.06 \mathrm{~m}$ and changed the median depth-averaged velocities by 0.0 to $0.02 \mathrm{~m} / \mathrm{s}$.

Table 4. Sensitivity analysis and results of the multidimensional flow model for simulated streamflows in the meanderstraight reach, Kootenai River near Bonners Ferry, Idaho.

[Streamflow for river model simulation: The model was constructed with a variable drag coefficient for the 170,566 , and $1,130 \mathrm{~m}^{3} / \mathrm{s}$ streamflowmanagement scenarios. Drag coefficient: Shading indicates a drag coefficient (dark shading) specified for the reach between the upstream boundary of the model and Ambush Rock and a different drag coefficient (light shading) specified for the reach between Ambush Rock and the downstream boundary of the model. No shading indicates a single drag coefficient. Sensitivity analyses of the calibrated drag coefficient were made for the 170 , 1,130, and $2.120 \mathrm{~m}^{3} / \mathrm{s}$ streamflow-management scenarios at $\mathbf{8 5}$ (bold, italic) and $\mathbf{1 1 5}$ (bold) percent of the drag coefficient value. Reported median and maximum values are based on the population of all wet nodes in the model. Abbreviations: $\mathrm{m}^{3} / \mathrm{s}$, cubic meter per second; $\mathrm{ft}^{3} / \mathrm{s}$, cubic foot per second; m, meter; ft, foot; Med., median; Max., maximum; m/s, meter per second; ft/s, foot per second; -, no data]

\begin{tabular}{|c|c|c|c|c|c|c|c|c|c|c|c|c|c|c|}
\hline \multirow{2}{*}{\multicolumn{2}{|c|}{$\begin{array}{l}\text { Streamflow for } \\
\text { river model } \\
\text { simulation }\end{array}$}} & \multirow{3}{*}{$\begin{array}{c}\text { Drag } \\
\text { coefficient }\end{array}$} & \multicolumn{4}{|c|}{ Depth } & \multicolumn{4}{|c|}{ Velocity } & \multicolumn{4}{|c|}{ Water-surface elevation } \\
\hline & & & \multicolumn{2}{|c|}{ (m) } & \multicolumn{2}{|c|}{ (ft) } & \multicolumn{2}{|c|}{$(\mathrm{m} / \mathrm{s})$} & \multicolumn{2}{|c|}{$(\mathrm{ft} / \mathrm{s})$} & \multicolumn{2}{|c|}{ (m) } & \multicolumn{2}{|c|}{ (ft) } \\
\hline $\mathrm{m}^{3} / \mathrm{s}$ & $\mathrm{ft}^{3} / \mathrm{s}$ & & Med. & Max. & Med. & Max. & Med. & Max. & Med. & Max. & Med. & Max. & Med. & Max. \\
\hline \multirow[t]{6}{*}{170} & 6,000 & 0.0131 & 4.43 & 21.89 & 14.53 & 71.83 & 0.25 & 1.30 & 0.81 & 4.27 & 532.73 & 533.51 & $1,747.80$ & $1,750.36$ \\
\hline & & .0056 & - & - & - & - & - & - & - & .00 & - & - & - & - \\
\hline & & .0111 & 4.42 & 21.89 & 14.51 & 71.82 & .25 & 1.31 & .82 & 4.31 & 532.72 & 533.61 & $1,747.77$ & $1,750.69$ \\
\hline & & .0048 & - & - & - & - & - & - & - & - & - & - & - & - \\
\hline & & .0151 & 4.44 & 21.90 & 14.56 & 71.84 & .25 & 1.20 & .81 & 3.92 & 53274 & 533.49 & $1,747.83$ & $1,750.30$ \\
\hline & & .0064 & - & - & - & - & - & - & .00 & .00 & - & - & - & - \\
\hline \multirow[t]{2}{*}{566} & 20,000 & .0057 & 5.86 & 23.53 & 19.23 & 77.19 & .58 & 1.31 & 1.89 & 4.30 & 534.54 & 535.04 & $1,753.74$ & $1,755.38$ \\
\hline & & .0033 & - & - & - & - & - & - & - & .00 & - & - & - & - \\
\hline \multirow[t]{6}{*}{1,130} & 40,000 & .0030 & 7.51 & 25.37 & 24.63 & 83.22 & .85 & 1.61 & 2.78 & 5.30 & 536.48 & 536.95 & $1,760.10$ & $1,761.65$ \\
\hline & & .0017 & - & - & - & - & - & - & - & - & - & - & - & - \\
\hline & & .0026 & 7.48 & 25.36 & 24.53 & 83.21 & .85 & 1.65 & 2.79 & 5.41 & 536.45 & 536.94 & $1,760.01$ & $1,761.61$ \\
\hline & & .0014 & - & - & - & - & - & - & - & - & - & - & - & - \\
\hline & & .0035 & 7.54 & 25.39 & 24.74 & 83.28 & .83 & 1.58 & .28 & 5.19 & 536.51 & 537.07 & $1,760.20$ & 1,7204 \\
\hline & & .0020 & - & - & - & - & - & - & - & - & - & - & - & - \\
\hline 1,700 & 60,000 & .0016 & 9.09 & 27.14 & 29.82 & 89.04 & 1.00 & 1.80 & 3.28 & 5.90 & 538.31 & 538.91 & $1,766.11$ & 1,768.08 \\
\hline \multirow[t]{3}{*}{2,120} & 75,000 & .0020 & 9.78 & 28.59 & 32.10 & 93.81 & 1.00 & 1.70 & 3.27 & 5.57 & 539.75 & 540.52 & $1,770.83$ & $1,773.36$ \\
\hline & & .0017 & 9.77 & 28.59 & 2.54 & 93.81 & 1.00 & 1.77 & 3.28 & 5.81 & 539.72 & 540.45 & $1,770.73$ & $1,773.13$ \\
\hline & & .0023 & 9.80 & 28.61 & 32.15 & 93.86 & .99 & 165 & 3.26 & 5.41 & 539.78 & 547.59 & $1,770.93$ & $1,796.56$ \\
\hline
\end{tabular}




\section{Simulation of Streamflow in White Sturgeon Habitat}

The braided-straight reach and meander-straight reach models were used to simulate depths, depth-averaged velocities, bed shear stresses, and water-surface elevations in the Kootenai River for streamflows of 170, 566, 1,130, 1,700, and 2,120 $\mathrm{m}^{3} / \mathrm{s}$ (tables 2 and 4). The range of simulated streamflows was selected to span river conditions typical of those before and after the construction of Libby Dam. The highest streamflow $\left(2,120 \mathrm{~m}^{3} / \mathrm{s}\right)$ represents a discharge approximately equal to the annual median peak streamflow $\left(2,240 \mathrm{~m}^{3} / \mathrm{s}\right)$ prior to construction of Libby Dam in 1972 . The water-surface elevation at the downstream boundary of both models (table 5) was set for each streamflow condition using a one-dimensional model developed by Berenbrock (2005). Each simulated streamflow corresponds to the computed median water-surface elevations in Kootenay Lake at the Queens Bay gaging station (08NH064; fig. 1). A complete description of these conditions is in a report by Berenbrock (2006).

A few simple simulations are presented to demonstrate how the model can be used to link physical characteristics of streamflow to biological or other habitat data. Some measures of depth, velocity, and substrate composition generally are considered when assessing sturgeon spawning habitat (Parsley and others, 1993). Discussions of the model simulation include relating the model simulation of depth and velocity to observed patterns of spawning and egg locations. Adult sturgeon in the braided reach generally avoid minor channels and sloughs; therefore, the average depth and average velocity computed for the braided reach is based on model nodes only in the main channel and excludes any nodes in inundated minor channels and sloughs. Additionally, the average and maximum values of simulated depth and velocity were computed for cross-sections positioned every $100 \mathrm{~m}$ along the model reach.

\section{River Depth}

River depths are considerably shallower upstream of RKM 245.6 in the upper part of the straight reach and in the braided reach as compared to the lower and middle part of the straight reach and to the meander reach. Simulated depths averaged across cross sections positioned every 100 meters along the stream are shown in figure 9; maximum depths at each cross section are shown in figure 10. Simulated average depths in the main channel of the braided reach for the lowest and highest streamflow simulations were 2.4 and $6.7 \mathrm{~m}$ (fig. 9) and the average depths along the deepest part of the thalweg are 3.3 and $8.5 \mathrm{~m}$ (fig. 10). Downstream of Ambush Rock (fig. 2) in the meander reach, the average depths of the channel for the lowest and highest streamflow simulations were 4.8
Table 5. Upstream and downstream boundary conditions in simulations from the multidimensional flow models of the Kootenai River near Bonners Ferry, Idaho.

[Water-surface elevations for objective simulated flows correspond to median water-surface elevations at the Queens Bay gaging station in Kootenay Lake, British Columbia, Canada, and were computed using a 1-dimensional flow model (Berenbrock, 2005). Reported average water-surface elevations are based on the population of all wet nodes in the model. Abbreviations: $\mathrm{m}^{3} / \mathrm{s}$, cubic meter per second; $\mathrm{ft}^{3} / \mathrm{s}$, cubic foot per second; m, meter; $\mathrm{ft}$, foot]

\begin{tabular}{|c|c|c|c|c|c|}
\hline \multicolumn{2}{|c|}{$\begin{array}{l}\text { Streamflow for river } \\
\text { model simulations }\end{array}$} & \multicolumn{2}{|c|}{$\begin{array}{l}\text { Computed water- } \\
\text { surface elevation } \\
\text { at downstream } \\
\text { boundary of the } \\
\text { meander-straight } \\
\text { reach model }\end{array}$} & \multicolumn{2}{|c|}{$\begin{array}{l}\text { Simulated water- } \\
\text { surface elevation } \\
\text { for the upstream } \\
\text { boundary of the } \\
\text { braided-straight } \\
\text { reach model }\end{array}$} \\
\hline $\mathrm{m}^{3} / \mathrm{s}$ & $\mathrm{ft}^{3} / \mathrm{s}$ & $(\mathrm{m})$ & $(\mathbf{f t})$ & (m) & (ft) \\
\hline 170 & 6,000 & 532.09 & $1,745.70$ & 537.55 & $1,763.62$ \\
\hline 566 & 20,000 & 532.81 & $1,748.06$ & 539.78 & $1,770.93$ \\
\hline 1,130 & 40,000 & 533.74 & $1,751.12$ & 540.00 & $1,771.65$ \\
\hline 1,700 & 60,000 & 534.86 & $1,754.79$ & 540.80 & $1,774.29$ \\
\hline 2,120 & 75,000 & 535.84 & $1,758.01$ & 542.40 & $1,779.53$ \\
\hline
\end{tabular}

and $9.7 \mathrm{~m}$, respectively. The average depths along the deepest part of the thalweg are 8.00 and $15.0 \mathrm{~m}$ (fig. 10).

The river channel depth is greater than $13 \mathrm{~m}$ for the highest simulated flow at one location in the braided reach, at the downstream end of the straight reach, and throughout most of the thalweg in the meander reach (fig. 10). Near the upper end of the braided reach at RKM 253.7 the river impinges against a lone bedrock outcrop along the right bank resulting in a deep scour hole. The deepest points in the straight and meandering reaches are at Ambush Rock (RKM 244.5) and the Klockmann Ranch gaging station (12314000) at RKM 224.7 (fig. 2) where the river impinges against a bedrock outrcop and forms a scour hole. The maximum river depth at Ambush Rock and at the Klockmann Ranch gaging station is 20 and $21 \mathrm{~m}$ for the lowest simulated flow and 27 and $28 \mathrm{~m}$ for the highest simulated flow (ig. 10). Fishing for spawners for the KTOI Sturgeon hatchery has shown that white sturgeon use the scour hole at the Klockmann Ranch gaging station as a staging area prior to the spawning season (Jack Siple, Kootenai Tribe of Idaho, oral commun., 2007). During the spawning season, the farthest known upstream congregation of adult white sturgeon was observed in the scour hole at Ambush Rock. Fish telemetry has shown that some sturgeon use this hole as a staging area to swim into the straight reach and into the lower part of the braided reach (Pete Rust, Idaho Fish and Game, oral commun. 2006). Other deep areas in the meander reach are at the outside of channel bends where the curvature is highest such as the S-shaped meander near Myrtle Creek. 
During the 1994-2002 spawning seasons, egg collection in the Kootenai River indicated that sturgeon eggs tend to accumulate in deep water in the thalweg of the meander reach (Vaughn Paragamian, U.S. Fish and Wildlife Service, oral commun., 2005). Results from studies of white sturgeon spawning locations and simulated water depths (McDonald and others, 2004) and microhabitat criteria curves Parsley and Beckman (1994) can be interpreted that sturgeon may avoid spawning in the braided reach due to shallow water; however, other factors such as velocity patterns, hydraulic complexity, and site fidelity may influence sturgeon spawning patterns.

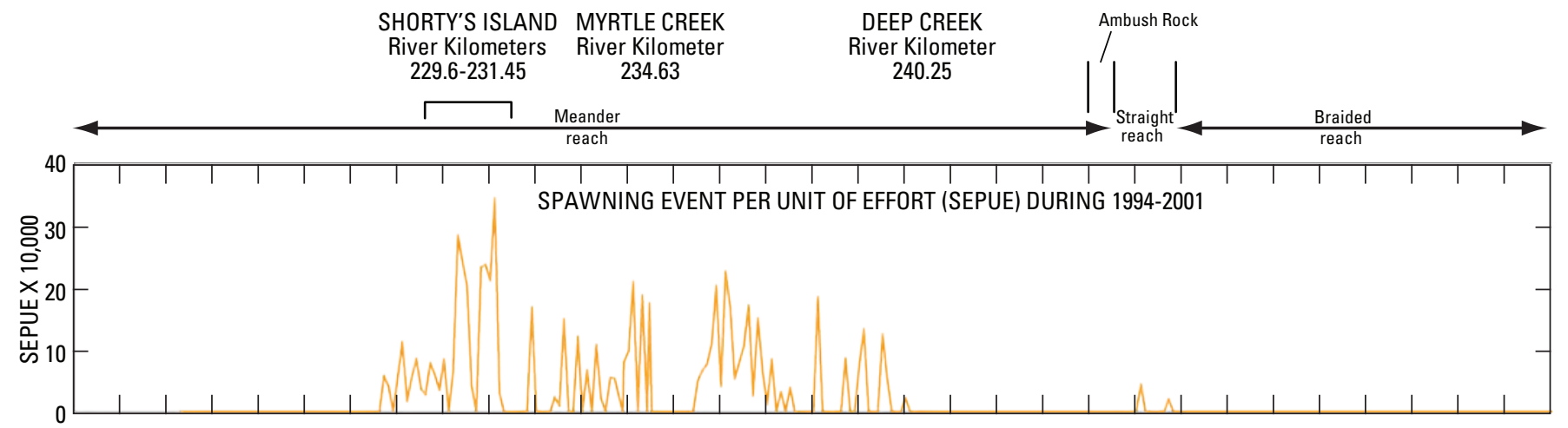

$222 \quad 223224225226227228229230231232 \quad 233234235236237238239240241242243244245246 \quad 247248249250251252253254$

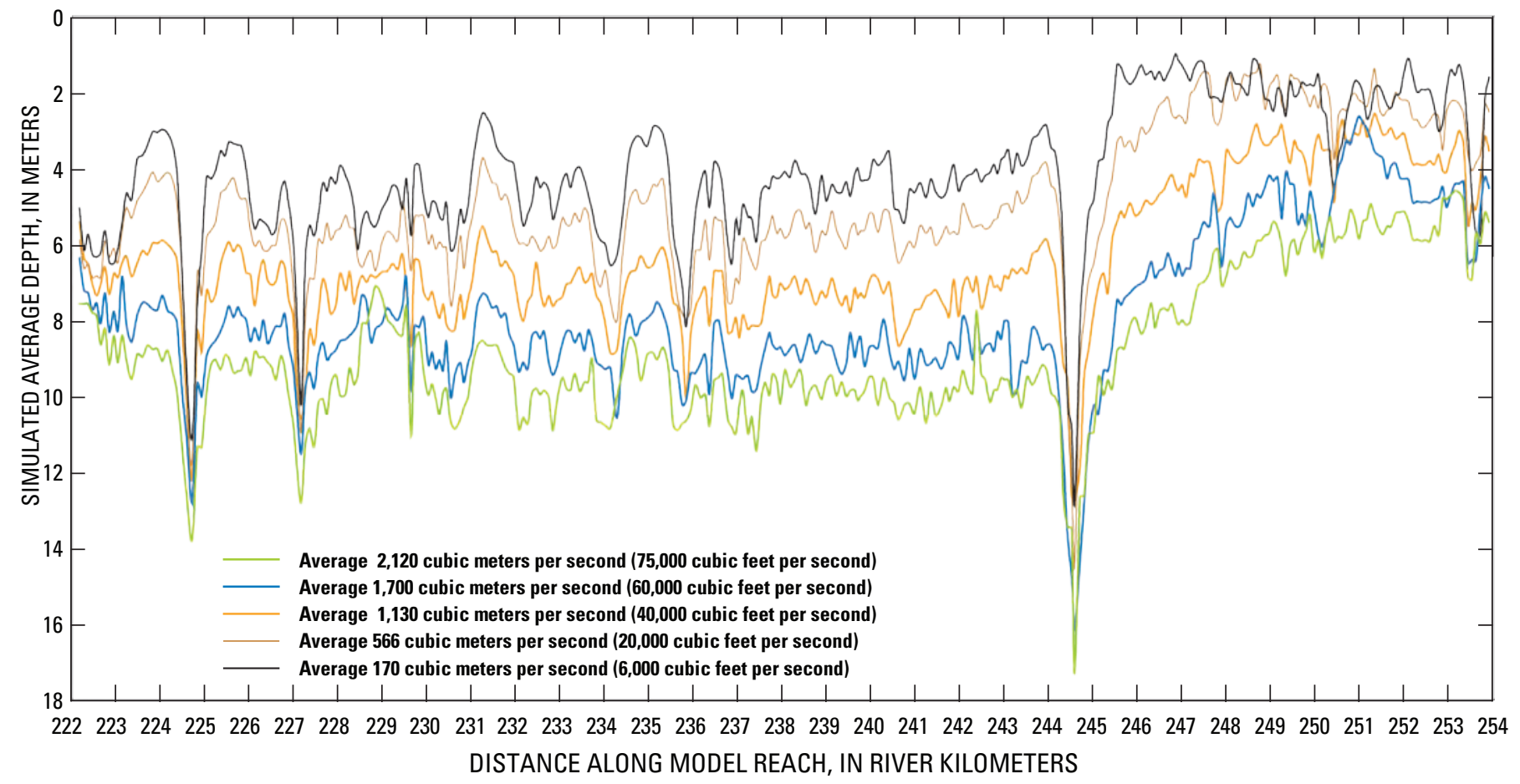

Figure 9. White sturgeon spawning event locations and simulated average depth for five streamflows at cross sections positioned every 100 meters along meander, straight, and braided reaches, Kootenai River near Bonners Ferry, Idaho. Spawning event per unit effort (SEPUE) was computed as the number of times fertilized eggs were detected on an egg mat resting on the riverbed at a sampling site divided by the time the mat was deployed (Paragamian and Wakkinen, Idaho Department of Fish and Game, written commun., 2005). 

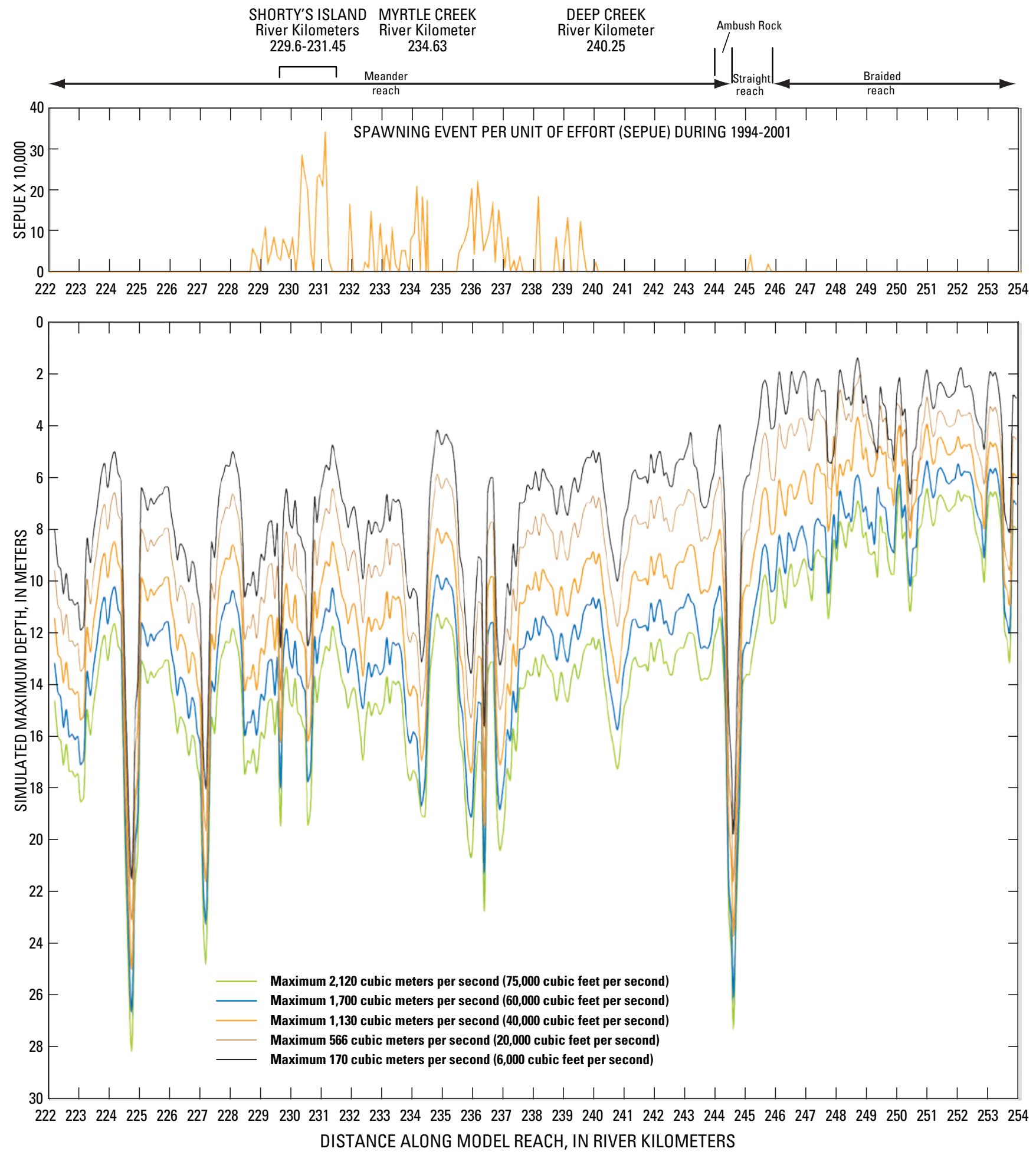

Figure 10. White sturgeon spawning event locations and maximum depth for five streamflows at cross sections positioned every 100 meters along the meander, straight, and braided reaches, Kootenai River near Bonners Ferry, Idaho. Spawning event per unit effort (SEPUE) was computed as the number of times fertilized eggs were detected on an egg mat resting on the riverbed at a sampling site divided by the time the mat was deployed (Paragamian and Wakkinen, Idaho Department of Fish and Game, written commun., 2005). 


\section{Simulated Streamflow Velocity}

Depth-averaged streamflow velocities in the braided reach were greater than velocities in the straight and meander reaches (fig. 11). In the main channel of the braided reach, the average depth-averaged velocities for the lowest and highest streamflow simulations were 1.1 and $1.3 \mathrm{~m} / \mathrm{s}$, respectively. The maximum depth-averaged velocities in the main channel for the lowest and highest streamflow simulations were 2.3 and $3.3 \mathrm{~m} / \mathrm{s}$. In the meander reach, average velocities for the lowest and highest streamflow simulations were 0.2 and $0.9 \mathrm{~m} / \mathrm{s}$. The maximum velocities for the lowest and highest streamflow simulations in the meander reach were 0.3 and $1.6 \mathrm{~m} / \mathrm{s}$.

The braided, straight, and meander reaches can be divided into four velocity zones based on simulated maximum depth-averaged velocity along the length of the model reach (fig. 11; Barton and others, 2005). The predominance of spawning in the downstream zone (zone D) and the model simulation results indicate that white sturgeon may be focusing on a specific velocity signature. Zone A, the main channel of the braided reach, is a region of high velocity except near RKM 248. Zone B, the straight reach, is a region of transition from the high velocity braided reach to the low velocity meander reach. At streamflows greater than about $566 \mathrm{~m}^{3} / \mathrm{s}$, backwater conditions extend upstream more than $1 \mathrm{~km}$ into the lower part of the braided reach resulting in decreased velocities that are somewhat similar to velocities in the straight and meander reaches. Between RKMs 249.3 and 250.0, the velocity increases as streamflow increases to $1,130 \mathrm{~m}^{3} / \mathrm{s}$. At higher streamflows, the velocity decreases due to backwater conditions extending farther upstream. Since 1994, IDFG has detected less than a few percent of the overall white sturgeon spawning in zone B. Maximum streamflow velocities are uniform compared with the rest of the meander model reach in zone $\mathrm{C}$ between Ambush Rock and the first sharp meander downstream of the mouth of Deep Creek at RKM 237.5. One notable exception is near the deep scour hole and lateral recirculation eddy upstream of Deep Creek located along the left bank. Less than 15 percent of the overall white sturgeon spawning has been detected in zone C (Paragamian and others, 2002). Maximum velocity increased with increasing streamflow and formed distinct zones of relatively high velocity in zone $\mathrm{D}$, downstream of zone $\mathrm{C}$, and extending to the downstream model boundary at RKM 222.1. Most white sturgeon spawning has been detected in zone D. McDonald and others (2004) reported that areas of relatively high velocity and white sturgeon spawning locations are correlated. Studies on the Columbia River indicate that sturgeon seek areas of high velocity for spawning (Parsley and others, 1993).

Streamflow velocities equal to or greater than $1.0 \mathrm{~m} / \mathrm{s}$ are believed to greatly reduce or eliminate predation of white sturgeon eggs (Bob Hallock, U.S. Fish and Wildlife Service, oral commun., 2005). The simulated average velocity in the spawning reach within the meander reach does not approach $1.0 \mathrm{~m} / \mathrm{s}$ until streamflow is about $2,120 \mathrm{~m}^{3} / \mathrm{s}$ (fig. 11). Based on maximum simulated velocity in the meander reach, velocities in parts of the channel approach $1.0 \mathrm{~m} / \mathrm{s}$ for streamflows roughly equal to or greater than $1,130 \mathrm{~m}^{3} / \mathrm{s}$. However, velocities in the main channel of the braided reach generally exceed the $1.0 \mathrm{~m} / \mathrm{s}$ threshold.

Flow structure at the white sturgeon spawning locations in the meander reach differs substantially from the flow structure in the braided reach (fig. 12). This difference could have some influence on the location of spawning events. McDonald and others (2006a) reported that areas of relatively high velocity and white sturgeon spawning locations are correlated. These areas of relatively high velocity occur in the meander reach at the same locations regardless of the discharge magnitude as modeled over a range of pre- and Libby Dam era flow conditions. In the braided reach, locations of regions of higher velocity are variable and shift on the order of kilometers in the upstream or downstream direction (fig. 11) under different backwater and streamflow conditions. This flow structure behavior can be attributed to the single-threaded meander reach having uniform channel geometry compared to the multi-threaded braided reach. As stage declines or the streamflow decreases to less than about $1,130 \mathrm{~m}^{3} / \mathrm{s}$ in the braided reach, the various minor channels and sloughs of the river begin to dewater causing the regions of higher velocity to change location. It is not known if white sturgeon can perceive the evolving velocity structure of the braided reach as too complex for spawning site selection. 


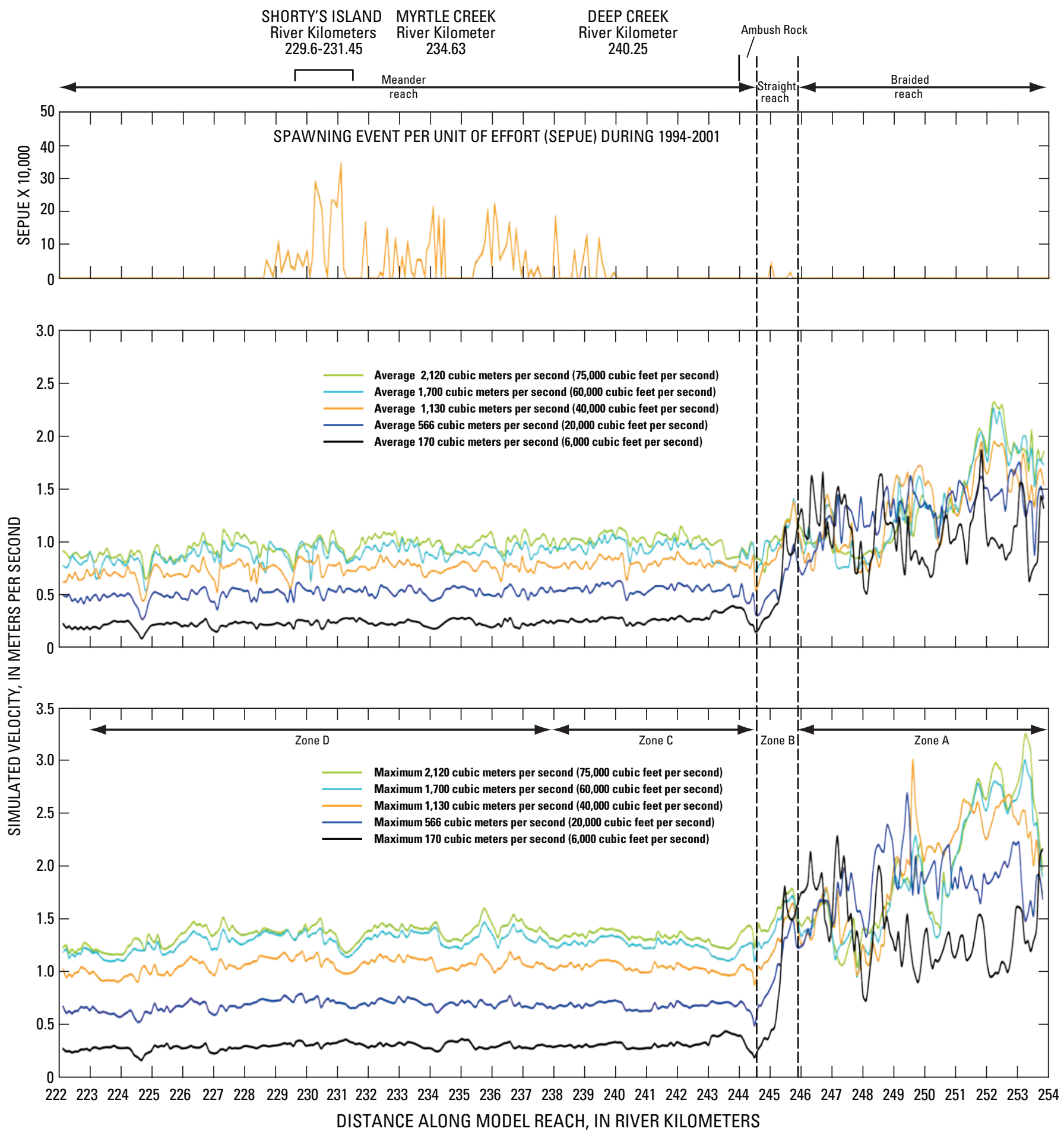

Figure 11. White sturgeon spawning event locations and simulated average and maximum velocity for five streamflows at cross sections positioned every 100 meters along the meander, straight, and braided reaches, Kootenai River near Bonners Ferry, Idaho. Spawning event per unit effort (SEPUE) was computed as the number of times fertilized eggs were detected on an egg mat resting on the riverbed at a sampling site divided by the time the mat was deployed (Paragamian and Wakkinen, Idaho Department of Fish and Game, written commun., 2005). 


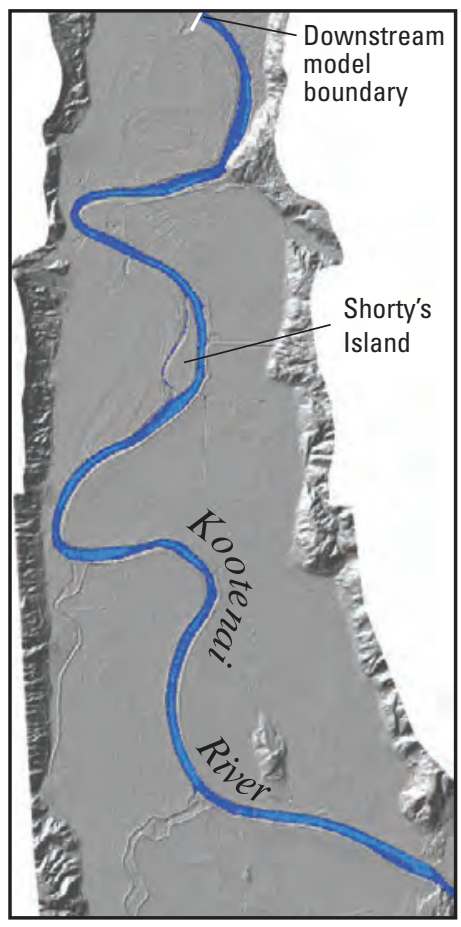

A. Simulated streamflow, 170 cubic meters per second.

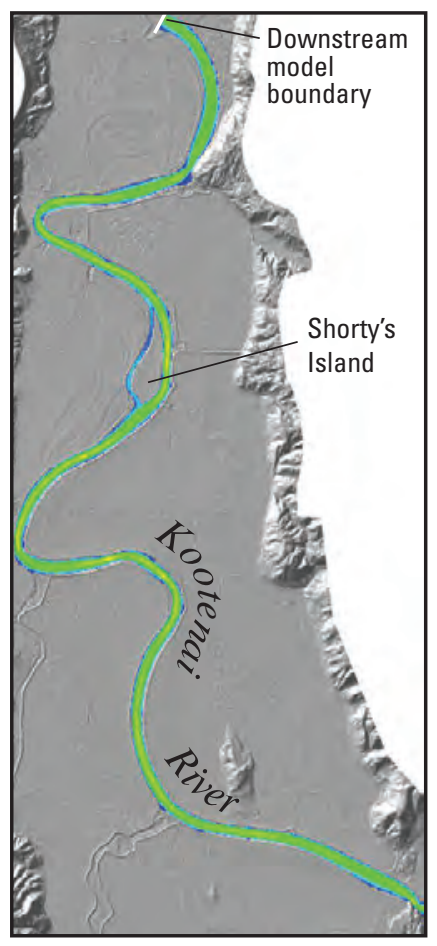

D. Simulated streamflow, 1,700 cubic meters per second.

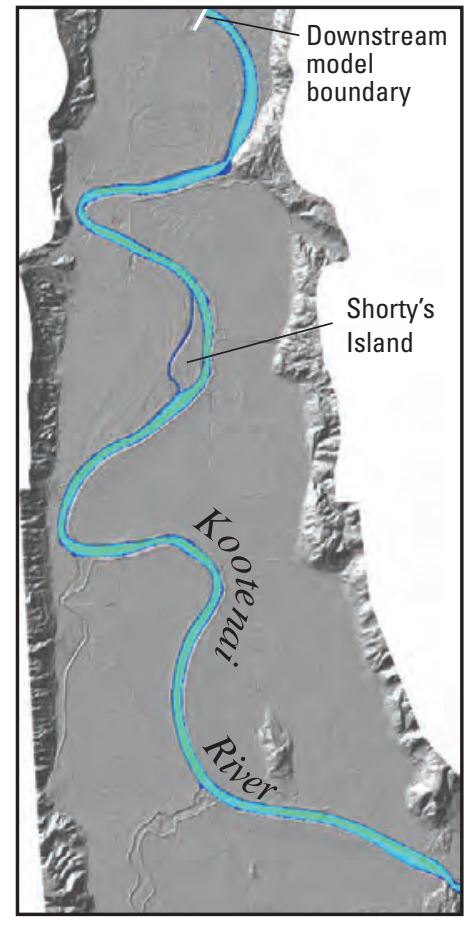

B. Simulated streamflow, 566 cubic meters per second.

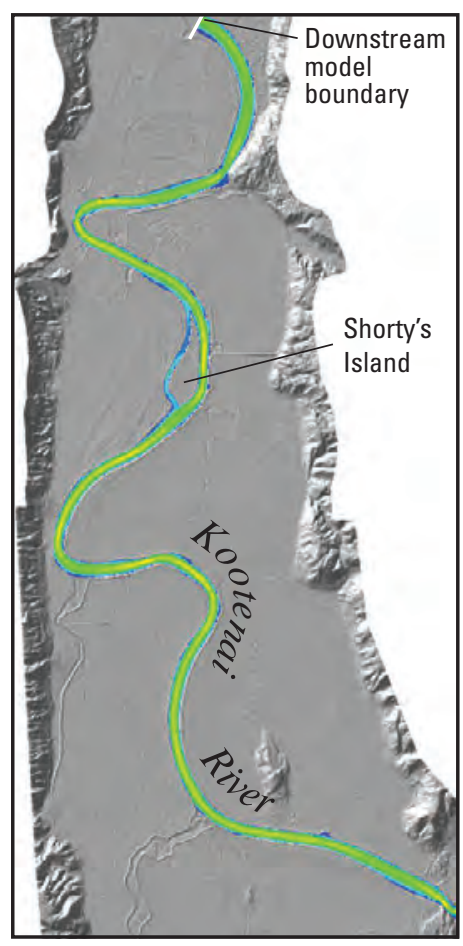

E. Simulated streamflow, 2,120 cubic meters per second.

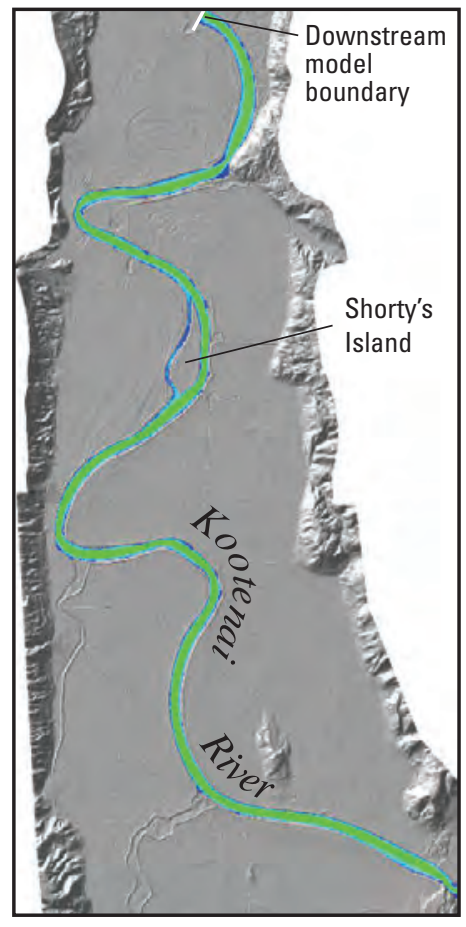

C. Simulated streamflow, 1,130 cubic meters per second.

\section{EXPLANATION} Meters per second

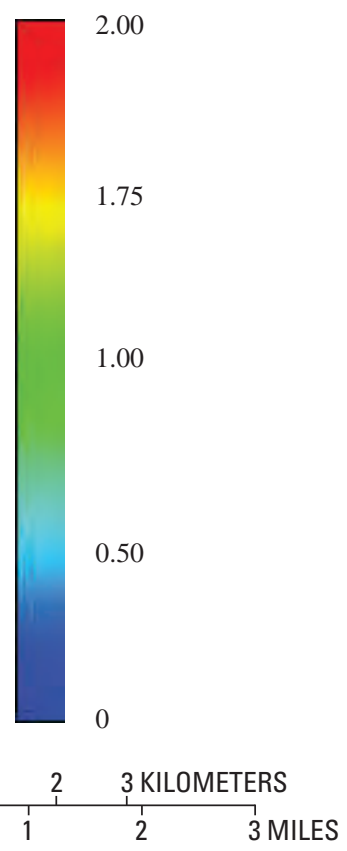

Figure 12. Distribution of simulated velocity for five streamflows in the meander, straight, and braided reaches, Kootenai River near Bonners Ferry, Idaho. Meander reach is shown above and the straight-braided reach is shown on the opposite page. 


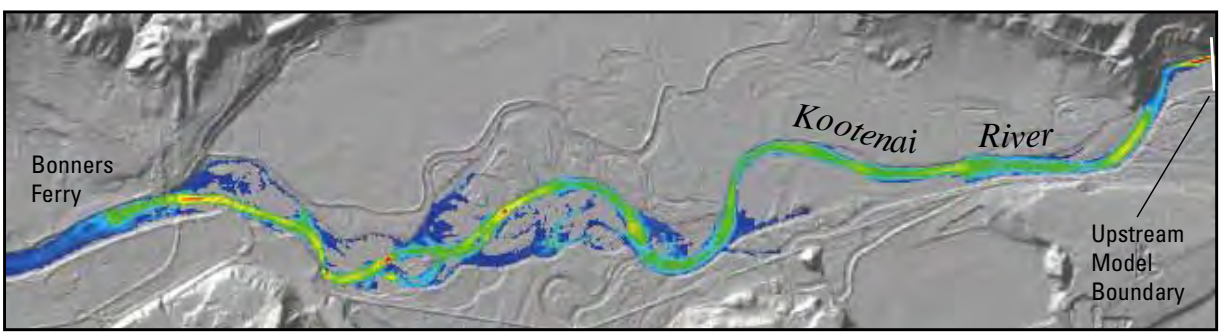

A. Simulated streamflow, 170 cubic meters per second-Continued

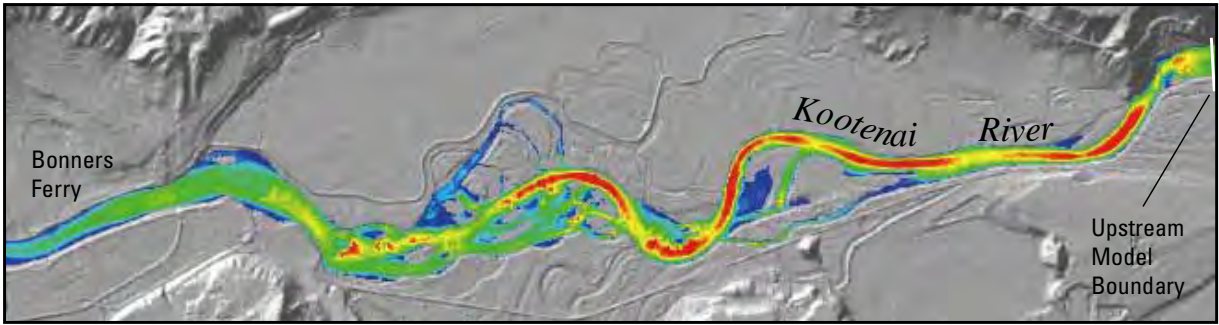

B. Simulated streamflow, 566 cubic meters per second-Continued

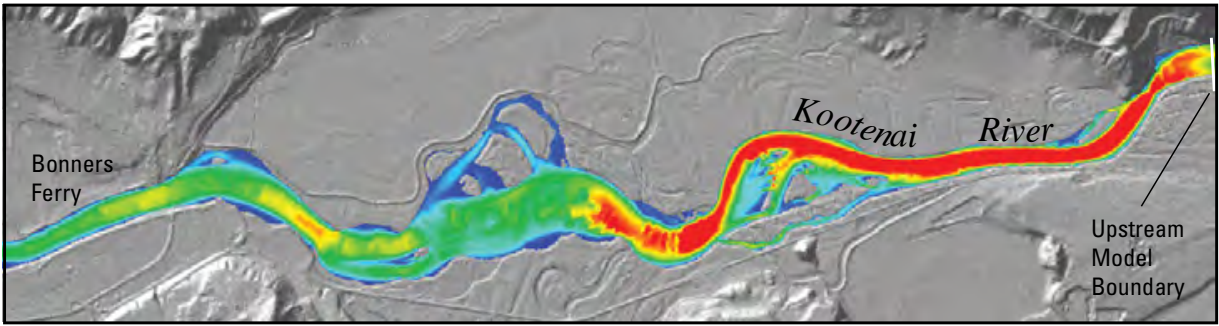

EXPLANATION Meters per second

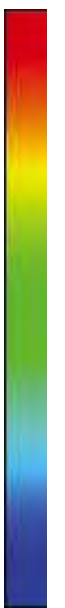

C. Simulated streamflow,1,130 cubic meters per second-Continued

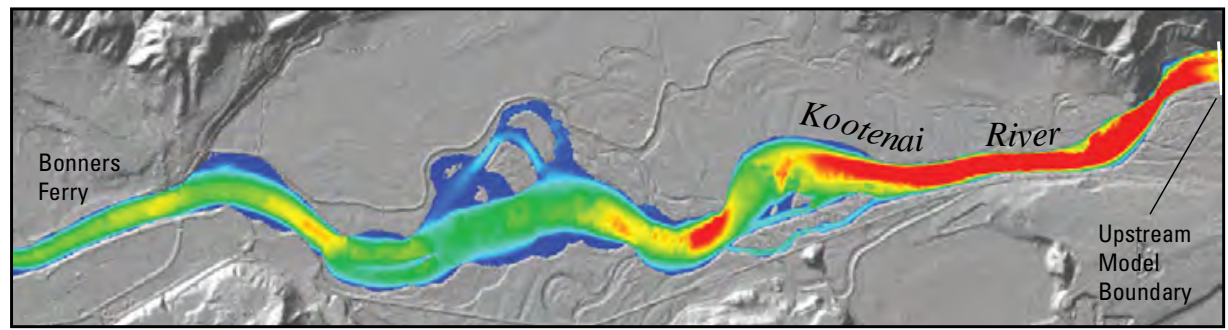

D. Simulated streamflow, 1,700 cubic meters per second-Continued

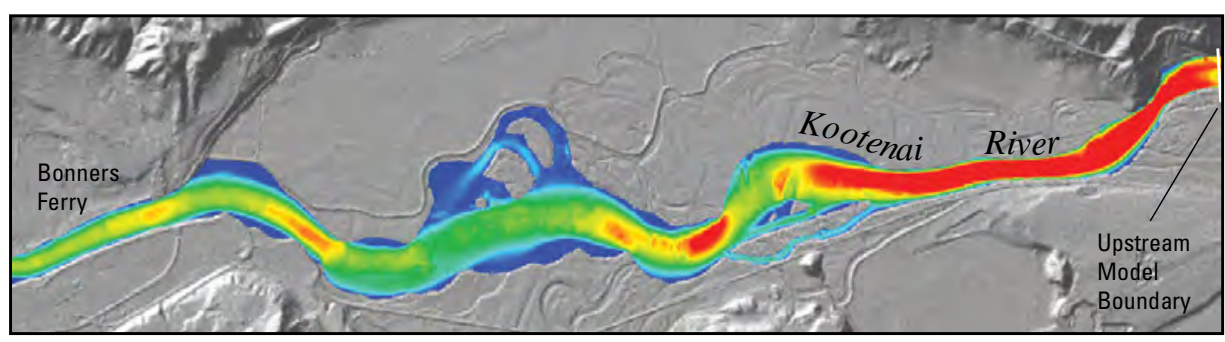

E. Simulated streamflow, 2,120 cubic meters per second-Continued

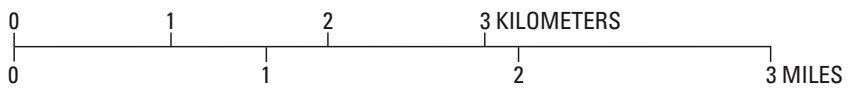

Figure 12. Continued. 


\section{Percentage of Braided and Straight Reach Meeting Habitat Criteria During White Sturgeon Spawning Season}

Output from the braided-straight reach model was used to report on the length and percentage of longitudinal profiles of the Kootenai River meeting the U.S, Fish and Wildlife Service 2006 Biological Opinion (BiOp; U.S, Fish and Wildlife Service, 2006) minimum habitat criteria for depth and streamflow velocity. Streamflow in the Kootenai River is augmented with water released from Libby Dam to benefit of white sturgeon migration, spawning, and downstream dispersal during the early life stages. This streamflow augmentation is summarized here and details are included in the 2006 Kootenai River BiOp (U.S. Fish and Wildlife Service, 2006), which addressed how the U.S. Army Corps of Engineers and the Bonneville Power Administration operate Libby Dam in Montana and the effect of dam operation on the endangered Kootenai River white sturgeon and its critical habitat. The BiOp specifies a minimum depth of 5-7 $\mathrm{m}$ or greater for 60 percent of the thalweg longitudinal profile between RKMs 244.6 and 252.7 during peak-flow augmentation. This habitat includes parts of the braided and straight reaches. Peak-flow augmentation is based on a full-powerhouse discharge of about $708 \mathrm{~m}^{3} / \mathrm{s}$ at Libby Dam, which generally occurs in mid-late May and early June during the white sturgeon spawning season (U.S. Fish and Wildlife Service, 2006). The depth criteria were established to ensure adequate depth for white sturgeon to swim upstream from the sandy meander reach into the braided reach and spawn where gravel and cobble substrate conditions are favorable for the survival of sturgeon eggs. Currently, less than 30 percent of sturgeon swim upstream into the braided reach (Pete Rust, Idaho Department of Fish and Game, oral commun., 2008). The depth criteria were evaluated by analyzing simulated depth from the braided-straight reach model for the period of peak flow augmentation during May 18 through June 5, 2006, and May 22 through June 5, 2007.

The BiOp also specifies a minimum streamflow velocity criterion of $1 \mathrm{~m} / \mathrm{s}$ in 60 percent of the maximum-velocity longitudinal profile between RKMs 244.6 and 252.7 during post-peak flow augmentation, for as many as 21 days. Post peak-flow augmentation occurs in mid-late June and early July during the white sturgeon spawning season. The velocity criterion is intended to provide large enough streamflow velocity to increase the likelihood of white sturgeon recruitment. Larger velocities reduce the ability of other fish species from preying on sturgeon eggs and aid egg incubation and downstream dispersal of sturgeon during early life stages. The streamflow velocity criterion was evaluated by analyzing simulated velocity from the braided-straight reach model for the period of post-peak flow augmentation on June 6-30, 2006 and 2007.

The thalweg longitudinal profile and the maximumvelocity longitudinal profile are in different locations. The thalweg longitudinal profile was fixed over the range of streamflows and the maximum-velocity longitudinal profile shifts laterally with different streamflows and backwater conditions in the multi-threaded braided reach. Backwater conditions in the braided reach are a function of streamflow and Kootenay Lake water-surface elevation. Day-to-day variability can occur in the location of the transition zone between the free-flowing river and backwater from Kootenay Lake. When the river is within its banks, streamflow velocity increases with increasing streamflow in the absence of backwater. However, when the river changes from an absence to a presence of backwater the streamflow velocity tends to decrease.

The braided-straight reach model was run for each day by specifying the mean daily discharge measured at the Tribal Hatchery gaging station (12310100). Mean daily watersurface elevations for the downstream model boundary were computed by interpolating measured water-surface elevations from the Bonners Ferry (12309500) and the Tribal Hatchery gaging stations.

The longitudinal-probe tool available in MD_SWMS was used to extract simulated depth for every model node along the thalweg longitudinal profile. These data were used to compute the length and percentage of the river's longitudinal profile that were within the depth criteria identified in table 6.

MD_SWMS was used to develop maps of simulated depth-averaged water velocity to evaluate the velocity criterion. A mapping approach was used to extract velocity from model simulations because the location of the maximumvelocity longitudinal profile shifts laterally with different streamflows and backwater conditions. Color-coded maps of simulated water velocity with $0.10 \mathrm{~km}$ markings along the river were used to evaluate the velocity criterion along a maximum-velocity longitudinal profile in the critical habitat reach. Data from these maps were manually extracted to compute the length and percentage of the river's maximumvelocity longitudinal profile in compliance with the velocity criterion (table 6). 
Table 6. Streamflow, surface-water elevation, and length and percentage of a longitudinal profile between river kilometers 244.6 and 252.7 meeting depth and velocity habitat criterion, Kootenai River near Bonners Ferry, Idaho, May 18-June 30, 2006, and May 22-June 30, 2007.

[Mean-daily water-surface elevations: computed by interpolation between the Bonners Ferry and Tribal Hatchery gaging station. Reported length of river meeting Kootenai River Biological Opinion minimum depth criteria of 5 meters in 60 percent of a longitudinal profile of the river between river kilometers 244.6 and 252.7 during peak flow augmentation from Libby Dam during the white sturgeon spawning season is based on depth output from the braided-straight reach model (U.S. Fish and Wildlife Service, 2006). Reported length of river meeting Kootenai River Biological Opinion minimum flow velocities of $1 \mathrm{~m} / \mathrm{s}$ or greater in 60 percent of a longitudinal profile of the river between river kilometers 244.6 and 252.7 during post-peak flow augmentation from Libby Dam during the white sturgeon spawning season is based on velocity output from the braided-straight reach model. Abbreviations: NAD29, North American Datum of 1929; NAVD88, North American Vertical Datum of 1988; m³/s, cubic meter per second; $\mathrm{ft} 3 / \mathrm{s}$, cubic foot per second; m, meter; ft, foot; m/s, meter per second; RM, river mile; RKM, river kilometer; N/A, criteria not applicable on specific date]

\begin{tabular}{|c|c|c|c|c|c|c|c|c|c|c|c|c|c|c|c|c|c|}
\hline \multirow{2}{*}{ Date } & \multicolumn{2}{|c|}{$\begin{array}{c}\text { Mean daily } \\
\text { streamflow } \\
\text { at Tribal } \\
\text { Hatchery } \\
\text { gaging } \\
\text { station }\end{array}$} & \multicolumn{6}{|c|}{ Mean-daily water-surface elevation } & \multicolumn{9}{|c|}{$\begin{array}{l}\text { Summary of longitudinal profile meeting the } \\
\text { depth and streamflow velocity criteria }\end{array}$} \\
\hline & s) & s) & $\begin{array}{l}\text { NAD29 } \\
(m)\end{array}$ & $\begin{array}{l}\text { NAD29 } \\
(\mathrm{ft})\end{array}$ & $\begin{array}{l}\text { NAVD88 } \\
(\mathrm{m})\end{array}$ & $\begin{array}{l}\text { NAVD88 } \\
\text { (ft) }\end{array}$ & $\begin{array}{l}\text { NAVD88 } \\
(\mathrm{m})\end{array}$ & $\begin{array}{l}\text { NAVD88 } \\
(\mathrm{ft})\end{array}$ & $\begin{array}{l}\text { Length, } \\
\text { in RKM }\end{array}$ & $\begin{array}{l}\text { Length, } \\
\text { in RM }\end{array}$ & & $\begin{array}{l}\text { Length, } \\
\text { in RKM }\end{array}$ & $\begin{array}{l}\text { Length, } \\
\text { in RM }\end{array}$ & & $\begin{array}{l}\text { Length, } \\
\text { in RKM }\end{array}$ & $\begin{array}{l}\text { Length, } \\
\text { in RM }\end{array}$ & \\
\hline \multicolumn{18}{|c|}{2006} \\
\hline 006 & 1,290 & 45,700 & 6.95 & 1.64 & 538.11 & 5.46 & 7.95 & $1,764.94$ & 7.16 & 4.45 & 8 & 3.01 & 1.87 & 34 & $\mathrm{~N} / \mathrm{A}$ & N/A & $\mathrm{N} / \mathrm{A}$ \\
\hline $05-19-2006$ & 1,220 & 42,900 & 537.09 & $1,762.09$ & 538.25 & $1,765.91$ & 538.11 & $1,765.47$ & 6.77 & 4.21 & 8 & 2.95 & 1.83 & 35 & N/A & $\mathrm{N} / \mathrm{A}$ & N/A \\
\hline 05-20-2006 & 1,310 & 46,300 & 537.27 & $1,762.70$ & 538.44 & $1,766.52$ & 538.30 & $1,766.07$ & 7.06 & 4.39 & 88 & 3.42 & 2.13 & 41 & N/A & N/A & N/A \\
\hline 05-21-2006 & 1,300 & 45,900 & 537.51 & $1,763.48$ & 538.67 & $1,767.30$ & 538.54 & $1,766.86$ & 6.65 & 4.13 & 91 & 3.81 & 2.37 & 44 & N/A & N/A & N/A \\
\hline 05-22-2006 & 1,220 & 42,900 & 537.30 & $1,762.81$ & 538.47 & $1,766.63$ & 538.34 & $1,766.22$ & 6.70 & 4.16 & 87 & 3.64 & 2.26 & 40 & N/A & N/A & N/A \\
\hline 05-23-2006 & 1,280 & 45,200 & 537.34 & $1,762.92$ & 538.50 & $1,766.74$ & 538.38 & $1,766.33$ & 6.70 & 4.16 & 8 & 3.78 & 2.35 & 42 & N/A & N/A & N/A \\
\hline 05-28-2006 & 1,040 & 36,600 & 536.55 & $1,760.35$ & 537.72 & $1,764.17$ & 537.61 & $1,763.80$ & 5.82 & 3.62 & 7 & 2.36 & 1.47 & 23 & N/A & N/A & N/A \\
\hline $05-29-2006$ & 1,030 & 36,500 & 536.43 & $1,759.95$ & 537.60 & $1,763.77$ & 537.49 & $1,763.40$ & 5.82 & 3.62 & 6 & 2.20 & 1.37 & 21 & N/A & N/A & N/A \\
\hline $05-30-2006$ & 1,020 & 35,900 & 536.37 & $1,759.75$ & 537.54 & $1,763.57$ & 537.42 & $1,763.20$ & 5.70 & 3. & 6 & 2.04 & 1.27 & 20 & N/A & N/A & N/A \\
\hline 05-31-2006 & 997 & 35,200 & 536.32 & $1,759.59$ & 537.49 & $1,763.41$ & 537.38 & $1,763.04$ & 5.15 & 3.20 & 6 & 2.03 & 1.26 & 20 & N/A & N/A & N/A \\
\hline 06-01-2006 & 986 & 34,800 & 536.28 & $1,759.45$ & 537.44 & $1,763.27$ & 537.33 & $1,762.90$ & 5.15 & 3.20 & 5 & 1.62 & 1.01 & 15 & N/A & N/A & N/A \\
\hline 06-02-2006 & 1,010 & 35,700 & 33 & $1,759.60$ & 537.49 & $1,763.42$ & 38 & $1,763.05$ & 5.10 & 3.17 & 6 & 1.92 & 1.19 & 19 & N/A & N/A & N/A \\
\hline 06-03-2006 & 1,040 & 36,600 & 42 & $1,759.92$ & 537.59 & $1,763.74$ & 47 & $1,763.37$ & 5.05 & 3.14 & 71 & 2.19 & 1.36 & 23 & N/A & N/A & N/A \\
\hline 06-04-2006 & 994 & 35,100 & 40 & $1,759.84$ & 537.56 & $1,763.66$ & 45 & $1,763.29$ & 5.10 & 3.17 & 68 & 91 & 1.19 & 23 & N/A & N/A & N/A \\
\hline 06-05-2006 & 1,020 & 36,200 & 536.44 & $1,759.99$ & 537.61 & $1,763.81$ & 537.50 & $1,763.44$ & 5.05 & 3.14 & 67 & 86 & 1.16 & 22 & N/A & N/A & N/A \\
\hline 06-06-2006 & 969 & 34,200 & & 68 & 537.51 & 50 & 40 & $1,763.14$ & N/A & N/A & N/A & /A & N/A & N/A & 65 & 3.51 & 70 \\
\hline $06-07-2006$ & 949 & 33,500 & & & 537 & & & 77 & A & & & & & & 32 & 2 & 72 \\
\hline 2006 & 994 & 35,100 & 30 & & 537.47 & & 53 & & 4 & $\mathrm{~N}$ & & 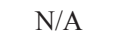 & $x$ & & 2 & 8 & 74 \\
\hline 06-09-2006 & 1,160 & 41,100 & 75 & 1,76 & 537.91 & 81 & .78 & 38 & A & $\mathrm{N}$ & & 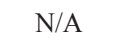 & $\mathrm{N}$ & & 0 & 4.04 & 81 \\
\hline 06-19-2006 & 1,730 & 61,000 & 538.44 & $1,766.54$ & 539.61 & $1,770.36$ & 539.46 & $1,769.87$ & N/A & N/A & N/ & N/A & N/A & $\mathrm{N} /$ & 7.67 & 4.77 & 95 \\
\hline $06-20-2006$ & 1,710 & 60,300 & 538.38 & $1,766.33$ & 539.54 & $1,770.15$ & 539.40 & $1,769.67$ & N/A & $\mathrm{N} /$ & $\mathrm{N} /$ & N/A & N/A & $\mathrm{N} /$ & 7.67 & 4.77 & 95 \\
\hline 06-21-2006 & 1,590 & 56,100 & 538.15 & $1,765.60$ & 539.32 & $1,769.42$ & 539.18 & $1,768.97$ & N/A & N/A & $\mathrm{N} /$ & N/A & N/A & N/A & 7.47 & 4.64 & 93 \\
\hline $06-22-2006$ & 1,460 & 51,400 & 537.74 & $1,764.24$ & 538.90 & $1,768.06$ & 538.77 & $1,767.62$ & N/A & N/A & $\mathrm{N} /$ & N/A & N/A & $\mathrm{N} /$ & 7.40 & 4.60 & 92 \\
\hline $06-23-2006$ & 1,270 & 44,900 & 537.27 & & & & & & N/A & N/A & $\mathrm{N}$ & N/A & N/A & N/ & 6.70 & 4.16 & 83 \\
\hline $06-24-2006$ & 1,090 & 38,600 & 536.78 & $1,761.08$ & 537.94 & $1,764.90$ & 537.82 & $1,764.51$ & N/A & N/A & N/ & N/A & N/A & N/A & 5.80 & 3.60 & 72 \\
\hline $06-25-2006$ & 997 & 35,200 & 536.37 & $1,759.76$ & 537.54 & $1,763.58$ & 537.42 & $1,763.20$ & N/A & N/A & N/A & N/A & N/A & N/A & 5.65 & 3.51 & 70 \\
\hline 06-26-2006 & 977 & 34,500 & 536.22 & $1,759.26$ & 537.39 & $1,763.08$ & 537.27 & $1,762.69$ & N/A & N/A & N/A & N/A & N/A & N/A & 5.75 & 3.57 & 71 \\
\hline 06-27-2006 & 898 & 31,700 & 535.95 & $1,758.35$ & 537.11 & $1,762.17$ & 537.00 & $1,761.80$ & N/A & N/A & N/A & N/A & N/A & N/A & 5.95 & 3.70 & 74 \\
\hline $06-28-2006$ & 813 & 28,700 & 535.58 & $1,757.15$ & 536.74 & $1,760.97$ & 536.64 & $1,760.62$ & N/A & N/A & N/A & N/A & N/A & N/A & 5.95 & 3.70 & 74 \\
\hline $06-29-2006$ & 787 & 27,800 & 535.44 & $1,756.69$ & 536.60 & $1,760.51$ & 536.49 & $1,760.15$ & N/A & N/A & N/A & N/A & N/A & N/A & 6.05 & 3.76 & 75 \\
\hline $06-30-2006$ & 782 & 27,600 & 535.34 & $1,756.37$ & 536.51 & $1,760.19$ & 536.39 & $1,759.82$ & N/A & N/A & N/A & N/A & N/A & N/A & 6.05 & 3.76 & 75 \\
\hline
\end{tabular}


Table 6. Streamflow, surface-water elevation, and length and percentage of a longitudinal profile between river kilometers 244.6 and 252.7 meeting depth and velocity habitat criterion, Kootenai River near Bonners Ferry, Idaho, May 18-June 30, 2006, and May 22-June 30, 2007.-Continued

[Mean-daily water-surface elevations: computed by interpolation between the Bonners Ferry and Tribal Hatchery gaging station. Reported length of river meeting Kootenai River Biological Opinion minimum depth criteria of 5 meters in 60 percent of a longitudinal profile of the river between river kilometers 244.6 and 252.7 during peak flow augmentation from Libby Dam during the white sturgeon spawning season is based on depth output from the braided-straight reach model (U.S. Fish and Wildlife Service, 2006). Reported length of river meeting Kootenai River Biological Opinion minimum flow velocities of $1 \mathrm{~m} / \mathrm{s}$ or greater in 60 percent of a longitudinal profile of the river between river kilometers 244.6 and 252.7 during post-peak flow augmentation from Libby Dam during the white sturgeon spawning season is based on velocity output from the braided-straight reach model. Abbreviations: NAD29, North American Datum of 1929; NAVD88, North American Vertical Datum of $1988 ; \mathrm{m}^{3} / \mathrm{s}$, cubic meter per second; $\mathrm{ft}^{3} / \mathrm{s}$, cubic foot per second; $\mathrm{m}$, meter; $\mathrm{ft}$, foot; $\mathrm{m} / \mathrm{s}$, meter per second; RM, river mile; RKM, river kilometer; N/A, criteria not applicable on specific date]

\begin{tabular}{|c|c|c|c|c|c|c|c|c|c|c|c|c|c|c|c|c|c|}
\hline \multirow{3}{*}{ Date } & \multirow{2}{*}{\multicolumn{2}{|c|}{$\begin{array}{c}\text { Mean daily } \\
\text { streamflow } \\
\text { at Tribal } \\
\text { Hatchery } \\
\text { gaging } \\
\text { station }\end{array}$}} & \multicolumn{6}{|c|}{ Mean-daily water-surface elevation } & \multicolumn{9}{|c|}{$\begin{array}{l}\text { Summary of longitudinal profile meeting the } \\
\text { depth and streamflow velocity criteria }\end{array}$} \\
\hline & & & \multicolumn{4}{|c|}{ Bonners Ferry gaging station } & \multicolumn{2}{|c|}{$\begin{array}{c}\text { Computed } \\
\text { downstream } \\
\text { boundary of } \\
\text { braided-straight } \\
\text { reach model }\end{array}$} & \multicolumn{3}{|c|}{$\begin{array}{c}\text { Minimum } \\
\text { water depth } \\
5 \text { meters }\end{array}$} & \multicolumn{3}{|c|}{$\begin{array}{l}\text { Minimum } \\
\text { water depth } \\
7 \text { meters }\end{array}$} & \multicolumn{3}{|c|}{$\begin{array}{l}\text { Minimum } \\
1 \mathrm{~m} / \mathrm{s} \text { velocity } \\
\text { criteria }\end{array}$} \\
\hline & $\left(\mathrm{m}^{3} / \mathrm{s}\right)$ & $\left(\mathrm{ft}^{3} / \mathrm{s}\right)$ & $\begin{array}{l}\text { NAD29 } \\
(m)\end{array}$ & $\begin{array}{c}\text { NAD29 } \\
(\mathrm{ft})\end{array}$ & $\begin{array}{l}\text { NAVD88 } \\
(\mathrm{m})\end{array}$ & $\begin{array}{l}\text { NAVD88 } \\
\text { (ft) }\end{array}$ & $\begin{array}{l}\text { NAVD88 } \\
(\mathrm{m})\end{array}$ & $\begin{array}{l}\text { NAVD88 } \\
\text { (ft) }\end{array}$ & $\begin{array}{l}\text { Length, } \\
\text { in RKM }\end{array}$ & $\begin{array}{l}\text { Length, } \\
\text { in RM }\end{array}$ & t & $\begin{array}{l}\text { Length, } \\
\text { in RKM }\end{array}$ & $\begin{array}{l}\text { Length, } \\
\text { in RM }\end{array}$ & nt & $\begin{array}{l}\text { Length, } \\
\text { in RKM }\end{array}$ & $\begin{array}{l}\text { Length, } \\
\text { in RM }\end{array}$ & \\
\hline $05-22-2007$ & 884 & 31,200 & 35.60 & $1,757.21$ & 536.76 & $1,761.03$ & 536.65 & $1,760.66$ & 6.00 & 3.73 & 46 & 1.33 & 0.83 & 10 & N/A & N/A & N/A \\
\hline $05-23-2007$ & 960 & 33,900 & 5.87 & 1,758.11 & 537.04 & $1,761.93$ & 536.94 & 1,761.61 & 6.26 & & $4 \varepsilon$ & 1.77 & & 14 & N/A & N/A & N/A \\
\hline $05-24-2007$ & 949 & 33,500 & 35.85 & $1,758.03$ & 537.01 & $1,761.85$ & 536.91 & $1,761.52$ & 7.16 & 4.45 & 55 & 1.85 & 1.15 & 14 & N/A & N/A & N/A \\
\hline $05-25-2007$ & 957 & 33,800 & 35.84 & $1,758.02$ & 537.01 & $1,761.84$ & 536.90 & $1,761.48$ & 7.17 & 4.46 & 55 & 1.85 & 1.15 & 14 & N/A & $\mathrm{N} / \mathrm{A}$ & /A \\
\hline $05-26-2007$ & 935 & 33,000 & 535.78 & $1,757.82$ & 536.95 & $1,761.64$ & 536.84 & $1,761.29$ & 7.03 & 4.37 & 54 & 1.79 & 1.11 & 14 & N/A & N/A & N/A \\
\hline 06-01-2007 & 971 & 34,300 & 35.99 & & 537.15 & & 537.06 & & & & & & & & & & \\
\hline 2007 & 969 & 34,200 & 5 & 1,75 & 53 & 1,7 & 3 & 1,7 & & & & & & & & A & N/A \\
\hline 06-03-2007 & 960 & 33,900 & 07 & $1,758.77$ & 537.24 & 1,76 & 537 & 1,76 & 7.66 & 4.76 & 59 & 0 & 1.24 & 15 & N/A & N/A & N/A \\
\hline 06-04-2007 & 960 & 33,900 & 536.10 & $1,758.86$ & 537.26 & $1,762.68$ & 537.17 & $1,762.37$ & 7.67 & 4.77 & 59 & 2.03 & 1.26 & 16 & N/A & N/A & N/A \\
\hline 06-05-2007 & 878 & 31,000 & 536.01 & $1,758.57$ & 537.18 & $1,762.39$ & 537.08 & $1,762.07$ & 7.15 & 4.44 & 55 & 1.91 & 1.19 & 15 & N/A & N/A & N/A \\
\hline 06-06-2007 & 838 & 29,600 & 535.85 & $1,758.04$ & 537.01 & $1,761.86$ & 536.93 & $1,761.58$ & $\mathrm{~N} / \mathrm{A}$ & N/A & N/A & N/A & N/A & N/A & 5.70 & 3.54 & 71 \\
\hline 06-07-2007 & 790 & 27,900 & 35.69 & $1,757.51$ & & $1,761.33$ & 536.77 & & & & & & N/A & $\mathrm{N} /$ & 5.90 & 3. & 73 \\
\hline 06-08-2007 & 691 & 24,400 & 41 & $1,756.58$ & 536.57 & $1,760.40$ & 48 & $1,760.10$ & 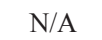 & & & 1 & N/A & N/A & 5.75 & 3.57 & 71 \\
\hline 06-09-2007 & 623 & 22,000 & 535.05 & $1,755.42$ & 536.22 & $1,759.24$ & 536.13 & $1,758.96$ & N/A & N/A & $\mathrm{N} /$ & $\mathrm{N} / \mathrm{A}$ & N/A & N/A & 5.95 & 3.70 & 74 \\
\hline $06-10-2007$ & 600 & 21,200 & 534.92 & $1,754.99$ & 536.09 & $1,758.81$ & 536.03 & $1,758.63$ & N/A & $\mathrm{N} / \mathrm{A}$ & $\mathrm{N} /$ & N/A & N/A & N/A & 6.05 & 3.76 & 75 \\
\hline 06-11-2007 & 612 & 21,600 & 534.89 & $1,754.88$ & 536.05 & $1,758.70$ & 535.99 & $1,758.50$ & N/A & $\mathrm{N} / \mathrm{A}$ & $\mathrm{N} /$ & $\mathrm{N} / \mathrm{A}$ & N/A & N/A & 6.10 & 3.79 & 76 \\
\hline 06-12-2007 & 595 & 21,000 & 534.79 & $1,754.56$ & 535.95 & $1,758.38$ & 535.89 & $1,758.17$ & N/A & N/A & $\mathrm{N} /$ & $\mathrm{N} / \mathrm{A}$ & N/A & N/A & 6.15 & 3.82 & 76 \\
\hline 06-13-2007 & 581 & 20,500 & 534.67 & $1,754.18$ & 535.84 & $1,758.00$ & 535.78 & $1,757.81$ & N/A & N/A & $\mathrm{N} /$ & $\mathrm{N} / \mathrm{A}$ & N/A & N/A & 6.10 & 3.79 & 76 \\
\hline $06-22-2007$ & 524 & 18,500 & 534.22 & $1,752.69$ & 535.38 & $1,756.51$ & 535.31 & $1,756.27$ & N/A & N/A & $\mathrm{N} / \mathrm{A}$ & $\mathrm{N} / \mathrm{A}$ & $\mathrm{N} / \mathrm{A}$ & N/A & 6.50 & 4.04 & 81 \\
\hline 06-23-2007 & 515 & 18,200 & 534.17 & $1,752.51$ & 535.33 & $1,756.33$ & 535.25 & $1,756.07$ & N/A & N/A & N/A & N/A & N/A & N/A & 6.55 & 4.07 & 81 \\
\hline $06-24-2007$ & 513 & 18,100 & 534.12 & $1,752.37$ & 535.29 & $1,756.19$ & 535.21 & $1,755.94$ & N/A & N/A & N/A & N/A & N/A & N/A & 6.50 & 4.04 & 81 \\
\hline $06-25-2007$ & 507 & 17,900 & 534.08 & $1,752.23$ & 535.24 & $1,756.05$ & 535.15 & $1,755.74$ & N/A & N/A & N/A & N/A & N/A & N/A & 6.65 & 4.13 & 83 \\
\hline $06-26-2007$ & 507 & 17,900 & 34.03 & $1,752.08$ & 535.20 & $1,755.90$ & 535.11 & $1,755.61$ & N/A & N/A & N/A & N/A & N/A & N/A & 6.68 & 4.15 & 83 \\
\hline $06-27-2007$ & 501 & 17,700 & 533.99 & $1,751.93$ & 535.15 & $1,755.75$ & 535.06 & $1,755.45$ & N/A & N/A & N/A & N/A & N/A & N/A & 6.80 & 4.23 & 85 \\
\hline 06-28-2007 & 496 & 17,500 & 533.94 & $1,751.77$ & 535.10 & $1,755.59$ & 535.01 & $1,755.28$ & N/A & N/A & N/A & N/A & N/A & N/A & 6.85 & 4.26 & 85 \\
\hline $06-29-2007$ & 490 & 17,300 & 533.90 & $1,751.64$ & 535.06 & $1,755.46$ & 535.97 & $1,758.43$ & N/A & N/A & $\mathrm{N} / \mathrm{A}$ & $\mathrm{N} / \mathrm{A}$ & $\mathrm{N} / \mathrm{A}$ & N/A & 7.05 & 4.38 & 88 \\
\hline 06-30-2007 & 487 & 17,200 & 533.88 & $1,751.57$ & 535.04 & $1,755.39$ & 534.94 & $1,755.05$ & N/A & N/A & N/A & N/A & N/A & N/A & 7.15 & 4.44 & 89 \\
\hline
\end{tabular}


The 5-m depth criterion for the braided-straight reach longitudinal profile was met every day from May 18 to June 5, 2006 (table 6) except for June 1 when streamflow was the lowest at $986 \mathrm{~m}^{3} / \mathrm{s}$. Mean daily streamflows from May 18 to June 5, 2006 ranged from 986 to $1,310 \mathrm{~m}^{3} / \mathrm{s}$, and the longitudinal profile meeting this habitat criterion ranged from 58 to 91 percent. During 2006, only 17 percent of the tagged fish went upstream of the Route 95 Bridge and 7 percent went upstream of RKM 246.6 into the multi-channel braided reach, and yet spawning was still recorded downstream in the meander reach. During May 22 to June 5, 2007, the braidedstraight reach did not meet the 5-m depth criterion (table 6). Mean daily streamflow during this period ranged from 878 to
$980 \mathrm{~m}^{3} / \mathrm{s}$, and the thalweg longitudinal profile exceeding the water depth criterion ranged from 46 to 59 percent. During 2006 and 2007, the thalweg longitudinal profile meeting the 7-m habitat criterion ranged from 10 to 44 percent. The relation between streamflow and percentage of the thalweg longitudinal profile between RKMs 244.6 and 252.7 that met the water depth criteria during 2006 and 2007 is shown in figure 13. Variability in the data indicates that depth can vary for a specific streamflow. Because depth in the braided reach is a function of streamflow and the water-surface elevation of Kootenay Lake, day-to-day variability can occur in the transition zone between the free-flowing river and backwater from Kootenay Lake.

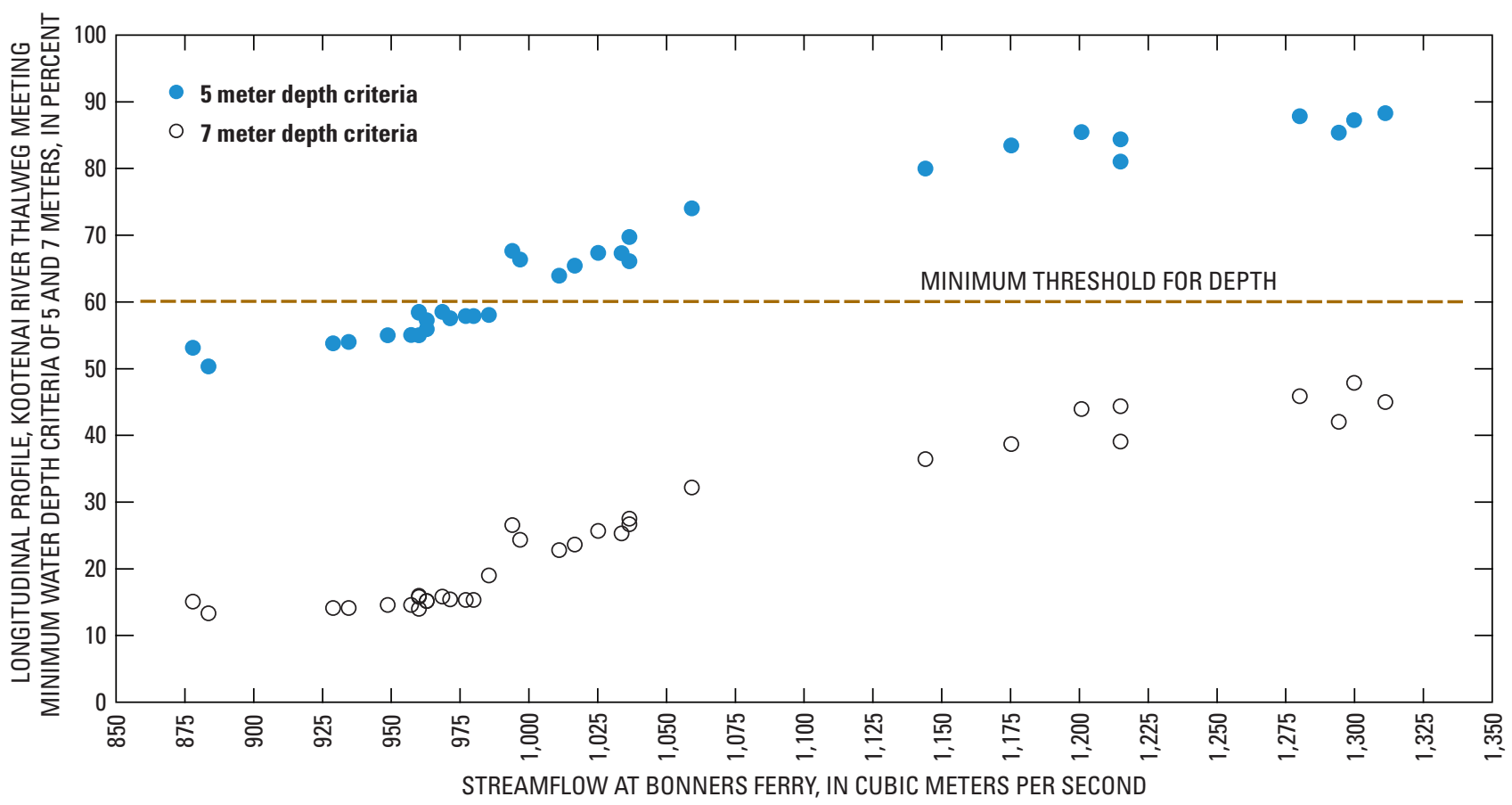

Figure 13. Streamflow and percentage of thalweg longitudinal profile achieving a minimum water depth of 5 and 7 meters between river kilometer 244.6 and 252.7, Kootenai River near Bonners Ferry, Idaho, May 18-June 5, 2006, and May 22-June 5, 2007. 
The streamflow velocity criteria were met each day during June 5-30, 2006 and 2007 (table 6). The maximumvelocity longitudinal profile of the river meeting the $1 \mathrm{~m} / \mathrm{s}$ velocity habitat criterion during this period ranged from 70 to 96 percent. The percentage of the maximum-velocity longitudinal profile meeting the velocity criterion varied for specific streamflows due to the day-to-day variability of the transition zone between the free-flowing river and backwater from Kootenay Lake in the braided reach. Figure 14 shows that as streamflow increases from about 500 to about $800 \mathrm{~m} / \mathrm{s}$ the percentage of the longitudinal profile meeting the velocity criterion decreases. This condition resulted from filling of Kootenay Lake, which lead to increased lake stage and backwater conditions that extended father upstream into the braided reach, which then decrease velocity. The percentage of the maximum-velocity longitudinal profile meeting the velocity criterion increases for streamflow greater than about $1,000 \mathrm{~m}^{3} / \mathrm{s}$.

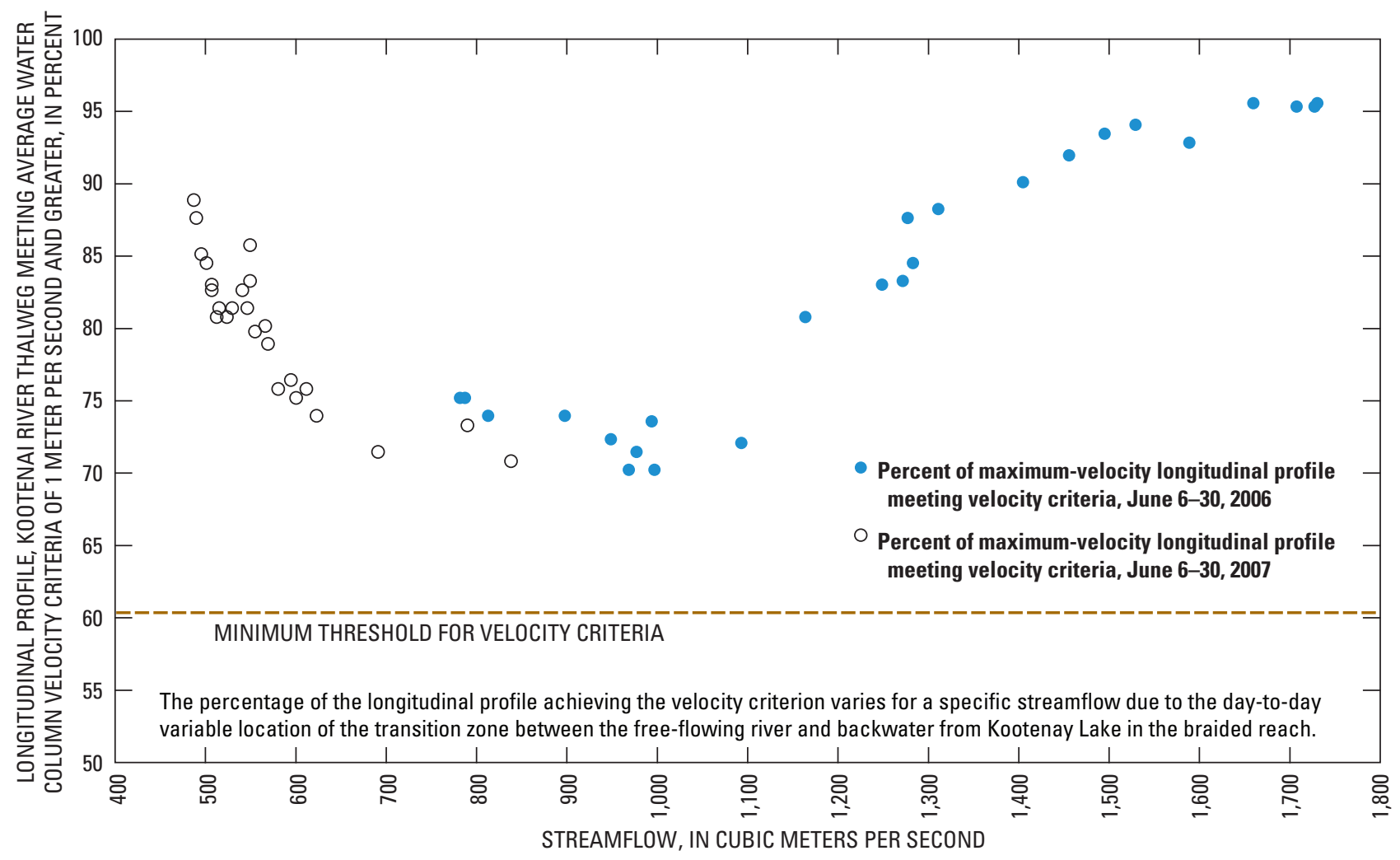

Figure 14. Streamflow and percentage of longitudinal profile achieving a minimum water column velocity of 1 meter per second between river kilometer 244.6 and 252.7, Kootenai River near Bonners Ferry, Idaho, June 6-30, 2006, and 2007. 


\section{Model Limitations}

Information on model limitations is presented in Barton and others (2005) and summarized here. The braided-straight and meander-straight reach multidimensional models are designed to simulate steady streamflows less than about $2,130 \mathrm{~m}^{3} / \mathrm{s}$. The models can simulate higher streamflows, but with increasing uncertainty in the model simulation results. The accuracy of simulations of the velocity flow field simulated by these models is constrained largely by (1) accuracy and amount of channel geometry data; (2) errors that could arise because channel geometry was measured during streamflows that varied between measurements; (3) uncertainty in the relation between streamflow and bedforms; (4) simplification of the roughness of the riverbed including bars, vegetation, and sediment on the riverbed, and of the river banks; and (5) potential errors incurred by applying a steady-state model to unsteady streamflow conditions. Additionally, the two-dimensional model cannot explicitly account for variations in velocity magnitude and direction in the vertical dimension. Therefore, streamflow dynamics adjacent to anthropogenic or natural vertical obstructions in the flow field would be better described using a fully 3-dimensional model. Similarly, the two-dimensional model treatment of turbulence is simple, and does not thoroughly describe flow patterns for areas in the river where undulating and complex bathymetry exist. Because of the complex computations and the requirement for more data collection, the beneficial return of an unsteady 3-dimensional, turbulence-resolving model probably is limited.

Another potential source of error results from the upstream boundary conditions input by the model user. Velocity magnitude and direction at the upstream boundary of the model grid have a profound effect on the simulated streamflow patterns in the upstream part of the modeling reach. Velocity conditions have been specified at the upstream boundary of the meander-straight reach model based on field measurements taken at the boundary during streamflows of 776 and 1,260 m³.s. However, velocity data were not available and thus velocity conditions were not specified for the upstream boundary of the braided-straight reach model. Velocity boundary conditions likely will vary for streamflow conditions that are greater or less than streamflow during field measurements.

Periodic updates to the braided-straight reach model are required to continue to accurately simulate hydraulic conditions in the braided reach into the future. The basis for this requirement is that bathymetry input into the braidedstraight reach model will, over time, misrepresent that reach because of shifting channels, scouring, and deposition. Therefore, the reach must be mapped periodically, the resulting bathymetry data input into the model, and the model recalibrated. Additionally, calibration of this model uses stream discharge measured at the Tribal hatchery gaging station that is computed using an index-velocity ratio. In the future, an adjustment may be applied to the computation that causes a shift in discharge over certain ranges of streamflow. This adjustment would take into account that the river has a mobile bed, and that changes in bed elevation across the channel at this gaging station may occur between low and high streamflow. As additional bed-elevation measurements are made at the gaging station and are evaluated for effect on flow, that information may be included in the discharge computations, and cause a shift in discharge over certain ranges of streamflow. Therefore, the model will need to be recalibrated to reflect this shift in discharge.

\section{Summary}

At the request of the Kootenai Tribe of Idaho, the U.S. Geological Survey (USGS) extend a two-dimensional flow model of the Kootenai River upstream into a braided reach that is upstream of the present-day white sturgeon spawning reach. Many scientists consider the braided reach a suitable substrate with adequate streamflow velocities for re-establishing recruitment of the endangered white sturgeon and that extending a model upstream will be helpful in assessing the feasibility of various strategies to encourage white sturgeon to spawn in this reach. At the request of the Idaho Department of Fish and Game (IDFG) the USGS also extended the older two-dimensional flow model several kilometers downstream of the white sturgeon spawning reach. This modified model can quantify the physical characteristics of a reach that white sturgeon pass through as they swim upstream from Kootenay Lake in British Columbia, Canada, to the spawning reach near Bonners Ferry, Idaho. The USGS Multi-Dimensional Surface-Water Modeling System was used for the initial modeling effort and for this subsequent modeling effort.

Two two-dimensional flow models of the Kootenai River braided, straight, and meander reaches form one contiguous $31.8 \mathrm{~km}$ model-simulated reach from river kilometer (RKM) 222.2 to 254.0 . The model of the braided reach extends from RKM 242.9 to 254.0 and includes the $2.8 \mathrm{~km}$ straight reach and a $1.6 \mathrm{~km}$ segment of the meander reach and is referred to as the braided-straight reach model. The previous USGS two-dimensional flow model of the meander reach includes the straight reach and is extended $6.2 \mathrm{~km}$ downstream; the model reach is from RKM 222.2 to 245.9 and referred as the meander-straight reach model. The computational grid used to model the Kootenai River braided, straight, and meander reaches forms an approximately $10 \times 10$-m grid. 
The braided-straight reach and meander-straight reach models were run over a range of streamflows to link physical characteristics of streamflow to biological or other habitat data. The models were used to simulate water-surface elevations, depth, velocity, and bed shear stress in the Kootenai River for streamflows of 170, 566, 1,130, 1,700, and $2,120 \mathrm{~m}^{3} / \mathrm{s}$. The range of simulated streamflows was selected to span typical river conditions before and after the construction of Libby Dam. The highest simulated streamflow $\left(2,120 \mathrm{~m}^{3} / \mathrm{s}\right)$ represents a discharge that is approximately equal to the annual median peak streamflow $\left(2,240 \mathrm{~m}^{3} / \mathrm{s}\right)$ prior to emplacement of Libby Dam in 1972. The water-surface elevation at the downstream boundary of both models was set for each streamflow condition using a one-dimensional model. The discharge for each streamflow condition corresponds to the median water-surface elevations in Kootenay Lake at the Queens Bay, British Columbia, Canada, (08NH064) gaging station.

Periodic updates to the braided-straight reach model are required to continue to accurately simulate hydraulic conditions in the braided reach into the future. The basis for this requirement is that bathymetry input into the braidedstraight reach model will, over time, misrepresent that reach because of shifting channels, scouring, and deposition. Therefore, the reach must be mapped periodically, the resulting bathymetry data input into the model, and the model recalibrated. Additionally, calibration of this model uses stream discharge measured at the Tribal hatchery gaging station that is computed using an index-velocity ratio. In the future, an adjustment may be applied to the computation that causes a shift in discharge over certain ranges of streamflow. This adjustment would take into account that the river has a mobile bed, and that changes in bed elevation across the channel at this gaging station may occur between low and high streamflow. As additional bed-elevation measurements are made at the gaging station and are evaluated for effect on flow, that information may be included in the discharge computations, and cause a shift in discharge over certain ranges of streamflow. Therefore, the model will need to be recalibrated to reflect this shift in discharge.

The braided, straight, and meander reaches can be divided into four distinct velocity zones on the basis of simulated maximum depth-averaged velocity; moreover, an analysis of simulated velocity indicates that white sturgeon may be focusing on a specific velocity signature. Zone A, the main channel of the braided reach, is a region of generally high velocity except near RKM 248. Zone B, the straight reach, is a transition zone from the high velocity braided reach to the low velocity meander reach. Since 1994, IDFG has detected less than a few percent of the overall white sturgeon spawning in zone $\mathrm{B}$. The contact between zone A and $\mathrm{B}$ is variable due to changing backwater conditions over the range of the streamflows. At streamflows greater than about $566 \mathrm{~m}^{3} / \mathrm{s}$, backwater conditions extend upstream more than $1 \mathrm{~km}$ into the lower part of the braided reach resulting in decreased velocities that are somewhat similar to velocities in the straight and meander reaches. Zone $\mathrm{C}$, between Ambush Rock and the first sharp meander downstream of the mouth of Deep Creek at RKM 237.5 has uniform maximum streamflow velocities compared to the rest of the meander reach. One notable exception is near the deep scour hole and lateral recirculation eddy upstream of Deep Creek. Less than 15 percent of the overall white sturgeon spawning has been detected in zone C. Maximum velocity increased with increasing streamflow and formed distinct areas of relatively high velocity in zone $\mathrm{D}$, downstream of zone $\mathrm{C}$ and extending to the downstream model boundary at RKM 222.1. These areas of relatively high velocity and white sturgeon spawning locations have been correlated. Studies on the Columbia River indicate that sturgeon seek areas of high velocity for spawning. Most white sturgeon spawning in the Kootenai River has been observed in zone D. Spawning locations and simulated depths indicate that sturgeon may avoid spawning in the braided reach due to shallower water.

Streamflow velocities equal to or greater than $1.0 \mathrm{~m} / \mathrm{s}$ are likely to greatly reduce or eliminate predation of white sturgeon eggs. Simulated depth-averaged velocity in the meander reach does not approach $1.0 \mathrm{~m} / \mathrm{s}$ until streamflow is about $2,120 \mathrm{~m}^{3} / \mathrm{s}$. Based on maximum simulated velocity in the meander reach, velocity in parts of the channel approach $1.0 \mathrm{~m} / \mathrm{s}$ for streamflows roughly equal to or greater than $1,130 \mathrm{~m}^{3} / \mathrm{s}$. However, velocities in the main channel of the braided reach, generally exceed the $1.0 \mathrm{~m} / \mathrm{s}$ threshold.

Flow structure at the white sturgeon spawning locations in the meander reach differs substantially from the flow structure in the braided reach. This difference could have some influence on the location of spawning events. Relatively high velocity and white sturgeon spawning locations have been correlated. These areas of relatively high velocity occur in the meander reach at the same locations regardless of the discharge magnitude as modeled over a range of pre- and Libby Dam era flow conditions. In the braided reach, locations of regions of higher velocity are variable and shift on the order of kilometers in the upstream or downstream direction under different backwater and streamflow conditions. This flow structure behavior can be attributed to the single-threaded meander reach having uniform channel geometry compared to the multi-threaded braided reach. As stage declines or the streamflow decreases to less than about $1,130 \mathrm{~m}^{3} / \mathrm{s}$ in the braided reach, the various minor channels and sloughs of the river begin to dewater causing the regions of higher velocity to change location. It is not known if white sturgeon can perceive the evolving velocity structure of the braided reach as too complex for spawning site selection. 
Output from the braided-straight reach model was used to report on the length and percentage of longitudinal profiles of the Kootenai River meeting the U.S. Fish and Wildlife Service Biological Opinion minimum criteria for depth and streamflow velocity during the May and June white sturgeon spawning season. During peak-flow augmentation the BiOp specifies a minimum depth criteria of 5 to $7 \mathrm{~m}$ or greater for 60 percent of the thalweg longitudinal profile between RKM 244.6 and 252.7. This habitat includes parts of the braided and straight reaches. The 5-m depth criterion for the braided-straight reach longitudinal profile was met every day from May 18 to June 5, 2006, except for June 1 when streamflow was the lowest (986 $\mathrm{m}^{3} / \mathrm{s}$ ). Mean daily streamflows from May 18 to June 5, 2006, ranged from 986 to $1,300 \mathrm{~m}^{3} / \mathrm{s}$, and the percentage of the longitudinal profile meeting the habitat criterion ranged from 58 to 91 percent. Although the 5-m depth criterion was met during 2006, only 17 percent of the tagged fish went upstream of the Route 95 Bridge and 7 percent went upstream of RKM 246.6 into the multichannel braided reach, and spawning was still recorded downstream in the meander reach. During May 22 to June 5, 2007, the braided-straight reach failed to meet the 5-m depth criterion. Mean daily streamflows during this period ranged from 878 to $980 \mathrm{~m}^{3} / \mathrm{s}$, and the percentage of the thalweg longitudinal profile exceeding the water depth criterion ranged from 46 to 59 percent. During 2006 and 2007, the percentage of the thalweg longitudinal profile meeting the 7-m habitat criterion ranged from 10 to 44 percent. The streamflow velocity criterion was met each day during June 5-30, 2006 and 2007. Percent of the maximum-velocity longitudinal profile of the river meeting the $1 \mathrm{~m} / \mathrm{s}$ velocity habitat criterion during this period ranged from 70 to 96 percent. The percent of the maximum-velocity longitudinal profile meeting the velocity criterion varies for a specific streamflow due to the day-to-day variable location of the transition zone between the free-flowing river and backwater from Kootenay Lake in the braided reach.

\section{Acknowledgments}

The authors thank the people of the Kootenai River Valley in Idaho who provided access to the Kootenai River for surveying. Sue Ireland of the Kootenai Tribe of Idaho provided storage facilities for USGS boats and equipment. Vaughn Paragamian, Diane Wakkinnen, and Peter Rust of Idaho Department of Fish and Game provided white sturgeon spawning and egg location data. The authors also thank Jack Siple of the Kootenai Tribe of Idaho who provided logistical support for fieldwork. Rick Backsen, John Gralow, and Russ Christensen, Post Falls, Idaho, and Edward Moran, Anchorage, Alaska, all with the U.S. Geological Survey, worked long hours collecting data on the Kootenai River for this project. Sandra Ball of U.S. Geological Survey in Post Falls, Idaho, helped with many logistic issues.

\section{References Cited}

Barton, G.J., 1998, Subbottom seismic-reflection profiling on the Kootenai River near Bonners Ferry, Idaho [abs.]: Proceedings of Ninth Annual Nonpoint Source Water Quality Monitoring Results Workshop, Boise, Idaho, 1 p.

Barton, G.J., 2004, Characterization of channel substrate, and changes in suspended sediment transport and channel geometry in white sturgeon spawning habitat in the Kootenai River near Bonners Ferry, Idaho, following the closure of Libby Dam: U.S. Geological Survey Water-Resources Investigations Report 03-4324, 102 p.

Barton, G.J., and Ireland, S., 2000, Simulation of sediment transport in white sturgeon spawning habitat and assessment of the feasibility of enhancing spawning substrate, Kootenai River, Idaho: Columbia Basin Fish and Wildlife Authority, accessed August 4, 2005, at http://www.cbfwa.org/FWProgram/ResultProposal. $\underline{\mathrm{cfm} ? P P I D=M C 2002000024009}$

Barton, G., McDonald, R., Berenbrock, C., Nelson, J., Ireland, S., and Paragamian, V., 2006a, Altered dynamics of the Kootenai River white sturgeon habitat-Historic and recent data and hydraulic-sediment-transport modeling [abs]: Anchorage, Alaska, Annual American Fisheries Society conference, September 17, 2006, 1 p.

Barton, Gary, McDonald, Richard, Nelson, Jonathan, Berenbrock, Charles, Donato, Mary, VanMetre, Peter, and Mahler, Barbara, 2006b, Altered dynamics of the Kootenai River white sturgeon spawning habitat and flow modeling in Proceedings of the Joint $8^{\text {th }}$ Federal Interagency Sedimentation Conference, and the $3^{\text {rd }}$ Federal Interagency Hydrologic Modeling Conference, Reno, Nev., April 2-6, 2006, 8 p., accessed January 30, 2007, at http://pubs.usgs. gov/misc reports/FISC 1947-2006/pdf/1st-7thFISCsCD/8thFISC/8thFISC Barton.pdf

Barton, G.J., McDonald, R.R., Nelson, J.M., and Dinehart, R.L., 2005, Simulation of flow and sediment mobility using a multidimensional flow model for the white sturgeon critical-habitat reach, Kootenai River near Bonners Ferry, Idaho: U.S. Geological Survey Scientific Investigations Report 2005-5230, 54 p. Available at http:// pubs.usgs.gov/sir/2005/5230/pdf/sir20055230.pdf

Barton, G., McDonald, R., Nelson, J., Tranmer, A., Ireland, S., and Paragamian, V., 2006c, Kootenai River white sturgeon habitat and hydrodynamic modeling [abs.]: Boise, Idaho, University of Idaho, Idaho Water Resources research symposia to support management of Idaho's waters, July 25, 2006, 1 p. 
Barton, G.J., Moran, E.H., and Berenbrock, Charles, 2004, Surveying cross sections of the Kootenai River between Libby Dam, Montana, and Kootenay Lake, British Columbia, Canada: U.S. Geological Survey Open-File Report 2004-1045, 25 p., accessed December 15, 2006, at http://id.water.usgs.gov/PDF/ofr041045/.

Berenbrock, Charles, 2005, 1D simulations of hydraulic characteristics in the white sturgeon spawning habitat of the Kootenai River near Bonners Ferry, Idaho: U.S. Geological Survey Scientific Investigations Report 2005-5110, 30 p. Available at http://pubs.usgs.gov/sir/2005/5110/.

Berenbrock, Charles, 2006, Simulations of hydraulic characteristics in an upstream extension of the White River spawning habitat of the Kootenai River near Bonners Ferry, Idaho - A supplement to Scientific Investigations Report 2005-5110: U.S. Geological Survey Scientific Investigations Report 2006-5110, 17 p. Available at http:// pubs.usgs.gov/sir/2006/5019/.

Berenbrock, Charles, and Bennett, J.P., 2005, Simulation of flow and sediment transport in the white sturgeon spawning habitat of the Kootenai River near Bonners Ferry, Idaho: U.S. Geological Survey Scientific Investigations Report 2005-5173, 43 p. Available at http://pubs.usgs.gov/ sir/2005/5173/.

Dinehart, R.L., 2003, Spatial analysis of ADCP data in streams, in Gray, J.R., ed., Proceedings of the Federal Interagency Sediment Monitoring Instrument and Analysis Research Workshop, September 9-11, 2003, Flagstaff, Arizona: U.S. Geological Survey Circular 1276, 8 p., accessed on January 21, 2007, at http://water.usgs.gov/osw/ techniques/sediment/sedsurrogate2003workshop/dinehart. pdf

Lisle, T.E., Nelson, J.M., Pitlick, J., Madej, M.A., and Barkett, B.L., 2000, Variability of bed mobility in natural, gravelbed channels and adjustments to sediment load at local and reach scales: Water Resources Research, v. 26, no. 12, p. 3743-3755.

McDonald, R.R., Barton, G.J., Nelson, J.M., and Paragamian, V., 2006a, Modeling hydraulic and sediment transport processes in white sturgeon spawning habitat on the Kootenai River, in Proceedings: The Joint 8th Federal Interagency Sedimentation and 3rd Federal Interagency Hydrologic Modeling Conference, Reno, Nevada, April 2-6, 2006, 8 p., accessed May 20, 2007, at http://pubs.usgs. gov/misc_reports/FISC 1947-2006/pdf/1st-7thFISCsCD/8thFISC/8thFISC McDonald.pdf
McDonald, R.R., Bennett, J.P., and Nelson, J.M., 2001, The USGS multi-dimensional surface water modeling system, in Proceedings of the Federal Interagency Sedimentation Conference, $7^{\text {th }}$, Reno, Nev., March 21-25, 2001: Reno, Nev., Subcommittee on Sedimentation, p. I-161-I-167.

McDonald, R.R., Nelson, J.M., Barton, G., and Paragamian, V., 2004, Flow and sediment-transport modeling of Kootenai River White Sturgeon spawning habitat [abs]: Eos, Transactions of the American Geophysical Union, v. 85, no. 47, Abstract H53B-1239.

McDonald, R.R., Nelson, J.M., and Bennett, J.P., 2006b, Multi-dimensional surface-water modeling system user's guide: U.S. Geological Survey Techniques in Water Resources Investigations 11-B2, 136 p.

McDonald, R.R., Nelson, J.M., Kinzel, P.J., and Conaway, J., 2006c, Modeling surface-water flow and sediment mobility with the Multi-Dimensional Surface Water Modeling System (MD_SWMS): U.S. Geological Survey Fact Sheet 2005-3078, 4 p.

Nelson, J.M., Bennett, J.P., and Wiele, S.M., 2003, Flow and sediment-transport modeling, in Kondolf, G.M., and Piegay, H., eds., Tools in fluvial geomorphology: Chichester, England, Wiley, p. 539-576.

Nelson, J.M., and McDonald, R.R., 1997, Mechanics and modeling of flow and bed evolution in lateral separation eddies: Bureau of Reclamation, Glen Canyon Environmental Studies Report, 69 p.

Nelson, J.M., and Smith, J.D., 1989, Flow in meandering channels with natural topography, in Inkeda, S., and Parker, G., eds., River meandering: Washington, D.C., American Geophysical Union Water Resources Monograph v. 12, p. 69-102.

Paragamian, V.L., Barton, G.J., and Ireland, S., 2001, Have we found the pre-Libby Dam spawning location of Kootenai River white sturgeon? [abs.]: Proceedings, Idaho Chapter of the American Fisheries Society Annual Meeting, Boise, Idaho, February 22-24, 2001, p. 1.

Paragamian, V.L., Wakkinnen, V.D., and Crews, G., 2002, Spawning locations and movement of Kootenai River white sturgeon: Journal of Applied Ichthyology, v. 18, 9 p.

Parsley, M.J., and Beckman, L.G., 1994, White sturgeon spawning and rearing habitat in the lower Columbia River: North American Journal of Fish Management, v. 14, p. 812-827. 
Parsley, M.J., Beckman, L.G., and McCabe, G.T., Jr., 1993, Spawning and rearing habitat used by white sturgeon in the Columbia River downstream of McNary Dam: Transactions of the American Fisheries Society, v. 122, p. 217-227.

Tetra Tech, Inc., 2003, Kootenai River geomorphic assessment: Seattle, Wash., Tetra Tech, Inc., 114 p.

Thompson, D.M., Nelson, J.M., and Wohl, E.E., 1998, Interactions between pool geometry and hydraulics: Water Resources Research, v. 34, no. 12, p. 3673-3681.

U.S. Fish and Wildlife Service, 1999, Recovery plan for the Kootenai River population of the white sturgeon (Acipenser transmontanus): Portland, Oreg., U.S. Fish and Wildlife Service, variously paginated.
U.S. Fish and Wildlife Service, 2000, Biological opinion on effects to listed species from operation of the Federal Columbia River Power System: Portland, Oreg., U.S. Fish and Wildlife Service, variously paginated.

U.S. Fish and Wildlife Service, 2006, Biological opinion on effects to listed species from operation of the Federal Columbia River Power System: Portland, Oreg., U.S. Fish and Wildlife Service, variously paginated.

Wu, F.C., Shen, H.W., and Chou, Y.J., 1999, Variation of roughness coefficients for unsubmerged and submerged vegetation: Journal of Hydraulic Engineering, v. 125, no. 9, p. 934-942. 
This page intentionally left blank. 
Publishing support provided by the U.S. Geological Survey Publishing Network, Tacoma Publishing Service Center

For more information concerning the research in this report, contact the Director, Idaho Water Science Center

U.S. Geological Survey

230 Collins Road

Boise, Idaho 83702

http://id.water.usgs.gov 
总

맘

흘

움

言

牲

石

工.

을

중

ฮิ

꾼

兽

兽

亩

흘

0

覀

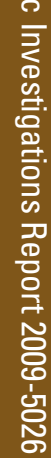

